\title{
ENTITLED TO WORK: URBAN PROPERTY RIGHTS AND LABOR SUPPLY IN PERU*
}

\author{
ERICA FIELD
}

Between 1996 and 2003, the Peruvian government issued property titles to over 1.2 million urban households, the largest titling program targeted at urban squatters in the developing world. This paper examines the labor market effects of increases in tenure security resulting from the program. To isolate the causal role of ownership rights, I make use of differences across regions induced by the timing of the program and differences across target populations in level of preprogram ownership rights. My estimates suggest that titling results in a substantial increase in labor hours, a shift in labor supply away from work at home to work in the outside market, and substitution of adult for child labor.

\section{INTRODUCTION}

Codifying and protecting property rights is seen in many academic discussions as requisite for economic development and poverty reduction. ${ }^{1}$ Among policy-makers, property titling is increasingly considered one of the most effective forms of government intervention for targeting the poor and encouraging economic growth (Binswanger et al. 1995; Baharoglu 2002). Despite the consensus on the importance of institutional factors for growth, there is a shortage of reliable evidence on the mechanisms by which property rights to land improve economic performance. Past microeconomic studies have focused almost exclusively on changes in investment incentives and credit access, with mixed results. ${ }^{2}$ This paper examines an alternative channel through which property rights can increase economic welfare: the efficiency gains from transferring the role of property protection from local communities and households to the state. A number of authors have

* I am indebted to Hank Farber and Anne Case for generous guidance on this project and to Daniel Andaluz in the COFOPRI office for providing the survey data. I also thank Attila Ambrus, David Autor, Melissa Clark, Javier Escobal, Eszter Hargittai, Chang-Tai Hsieh, Jeff Kling, Lewis Kornhauser, David Linsenmeier, Kristin Mammem, Máximo Torero, Diane Whitmore, and various seminar participants for numerous useful comments.

1. See Demsetz (1967), Alchian and Demsetz (1973), North (1981), Shleifer and Vishny (1993), and Acemoglu et al. (2001, 2002).

2. A large body of empirical work has examined these predictions. For instance, Feder et al. (1988), Besley (1995), Banerjee et al. (2002), and Field (2005) provide evidence that titles increase investment; Carter and Olinto (1996), Lopez and Romano (1997), and Alston et al. (1999) find that land titles improve access to credit; and Lanjouw and Levy (2002) find evidence that weak property rights increase transaction costs in rental and sales markets. Other work, such as Kimuyu (1994) and Place and Migot-Adholla (1998), detects little impact on investment.

(C) 2007 by the President and Fellows of Harvard College and the Massachusetts Institute of Technology.

The Quarterly Journal of Economics, November 2007 
noted that informal institutions frequently arise to compensate for lack of formal property protection, including community policing as well as individual homeowners guarding their land (Carter and Wiebe 1994; Galal and Razzaz 2001; Clay 2006). In these settings, an additional consequence of strengthening formal ownership rights is freeing up time previously devoted to solidifying informal claims. If untitled households expend human resources maintaining tenure security through informal means, shifting the burden of protection away from individuals and local institutions will reduce the opportunity cost of employment and enable households to make unconstrained decisions about time allocation across labor activities.

This paper looks for evidence of these relationships by examining the effect of increases in ownership security on household labor supply. A major obstacle to measuring the influence of tenure security is the potential endogeneity of land rights. I circumvent the problem by using variation in ownership rights arising from a nationwide program in Peru that issued formal property titles to more than 1.2 million urban households between 1995 and 2003. The Peruvian program was the first large-scale urban titling effort in the developing world and its impact has implications for many developing countries in which urban squatting is prevalent. Using data from a sample of program beneficiaries, I assess whether tenure security improvements associated with obtaining a property title increased labor hours and improved efficiency of labor allocation between home and market work and between child and adult labor. The fact that the program targeted nearly all untitled households regardless of demand and free of charge in large measure breaks the link between tenure security and income and helps isolate the causal effect of titling on market outcomes.

Two sources of variation in program influence are used to isolate the effect of titling: neighborhood start date and household ownership status prior to the program. Staggered program timing enables a comparison of households in neighborhoods already reached by the program with households in neighborhoods not yet reached. Meanwhile, variation in preprogram tenure security allows residents not subject to changes in security to serve as a quasi-control group for residents who experience relatively large changes in security as a result of the program. I also examine variation in program response related to household differences in the cost of maintaining informal rights. For this purpose, I use both residential tenure and household size as indicators of the 
security value of a property title for a particular household. Given that overall "de facto" property rights are observed to increase with residential tenure, the value of a property title and therefore the program impact should be lower for households with longer residential tenure (De Soto 1990; Lanjouw and Levy 2002). Likewise, since households with more adults have a greater capacity to provide home security, the security value of a formal title is predictably lower.

The paper contributes to the existing literature on property rights in two central ways. It is the first to examine the time cost of informal property protection, including distortions in time allocation across household members and categories of labor market activities. ${ }^{3}$ Second, the paper complements the existing literature on land rights by considering channels of welfare gain that are particularly relevant to urban households. Despite the fact that urban informality currently exceeds rural informality in most of the world, the literature to date has focused largely on rural households. ${ }^{4}$ Though advocates of property reform cite many of the same benefits to rural and urban land titling, urban employment and entrepreneurial activity are likely to be particularly sensitive to the degree of residential formalization given the greater opportunity cost of spending time at home in nonagricultural settings.

The resulting estimates of program impact suggest that households with no legal claim to property spend an average of 13.4 hours per week maintaining informal tenure security, reflecting a $14 \%$ reduction in total household work hours for the typical squatter family. Household members are also $40 \%$ more likely to work inside of their homes. Thus, the net effect of property titling is a combination of an increase in total labor force hours and a reallocation of work hours from inside the home to the outside labor market. Panel data estimates available for a subset of households support the cross-section results: the change in household labor supply between 1997 and 2000 was 16 hours per week greater for squatter households reached by the program, and these households were half as likely to start working at home during the

3. Lanjouw and Levy (2002) is one of the few papers to incorporate informal rights into a model of household responses to land titling. Their empirical study of urban squatter communities in Ecuador relates variation in the strength of informal rights to household characteristics rather than behavior. Similarly, Miceli et al. (2001) show that demand for titles in rural Kenya depends heavily on factors that contribute to the cost of maintaining informal rights.

4. An important exception is Galiani and Schargrodsky (2006), who study the impact of land titling in Buenos Aires. 
interval. Furthermore, the effect of obtaining a property title is decreasing in residential tenure and number of household members, consistent with the predictions that informal property rights and household size influence the home security demands facing untitled households. Finally, for households with fewer than four potential workers, titling is associated with a significant reduction in child labor hours, suggesting that in smaller households adults are disproportionately responsible for home security.

The fact that preprogram characteristics and labor hours in 1997 are independent of program timing suggests that the findings do not reflect permanent differences between treated and untreated areas. An important issue in interpreting the results is the possibility that the lower labor hours of squatters are driven by security concerns that arise in anticipation of the program. A number of empirical tests provide evidence that the program effect does not operate through temporary reductions in squatters' work hours. Most notably, in neighborhoods reached after the survey, future program timing is positively related to insecurity but unrelated to differences in labor supply between squatters and nonsquatters. Furthermore, anticipatory effects cannot explain observed differences in program impact according to year of entry.

\section{Project Background}

Peru's informal urban settlements grew out of the massive urban-rural migration that occurred over the last half-century as a result of the collapse of many traditional agrarian supply chains, ineffective agrarian reform, and the growth of guerilla movements. The existence of extensive barren land owned by the state on the perimeters of major cities, along with an implicit housing policy during the 1980s that allowed squatter settlements on unused government lands, led to an extended era of urban migration, often in the form of organized invasions by squatters from the same area of emigration (Olórtegui 2001). ${ }^{5}$ In 1997, an estimated one-fourth of Peru's urban population lived in marginal squatter settlements in periurban areas and many more untitled residents occupied inner-city neighborhoods (World Bank 1997).

Prior to the reforms, obtaining a property title was hampered by lengthy bureaucratic procedures and prohibitive fees.

5. Invasion of private property was allowed by law if the land had been unused for a period of four years. The law changed in 1990 so that invasions of private property were not allowed under any circumstance. 
As described in the initial project report: "Peru's traditional system of titling and registration is complex, inefficient, expensiveprohibitively so for poor people-and prone to rent-seeking. Fourteen different agencies are involved in the generation of each title ..." (World Bank 1998). ${ }^{6}$ Due to acute housing shortages and lack of legal transparency, tenants struggled not only with the government but also among themselves to secure residential properties. The common failure of the government to recognize informal rights in individual disputes gave rise to rent-seeking behavior in the form of invasions of untitled land (Olórtegui 2001).

In 1996, the Peruvian government issued a series of legal, administrative, and regulatory reforms aimed at promoting a formal property market in urban squatter settlements in eight cities. In accordance with Decree 424: Law for the Formalization of Informal Properties, the new public agency COFOPRI (Committee for the Formalization of Private Property) embarked on "the rapid conversion of informal property into securely delineated land holdings by the issuing and registering of property titles" into a newly created national registry (World Bank 1998). While the old process of acquiring a title was expensive and slow, the new process was virtually free and extremely rapid. Program implementation involved area-wide titling, in which project teams moved from neighborhood to neighborhood within cities. Once a local property registration system was set up, local program officials were trained, and all lots in the city's informal neighborhoods were digitally mapped, several project teams simultaneously entered neighborhoods starting from different points in the city. ${ }^{7}$ To receive a title, claimants were required only to verify residence on eligible properties pre-dating the start of the program. ${ }^{8}$ As a result of the reforms, by December 2001 nearly 1.2 million of the country's previously unregistered residents became nationally registered property owners, purportedly affecting 6.3 million residents living in the range from just above to below the poverty line.

6. In his groundbreaking study, de Soto (1990) documented the same phenomenon: "[T] get title to a house in an informal settlement ... took 728 steps from one agency alone, and ten other agencies also required approval."

7. In campaigns of two months, project teams entered fifty to seventy neighborhoods encompassing 30,000 to 35,000 plots. Within neighborhoods, teams spent five to seven weeks establishing claims and delineating properties before conferring titles. Registration took an additional one to six months. See Field (2003) for a detailed overview of the process.

8. Ineligible properties include archeological sites and flood planes, among other exceptions. In the COFOPRI data, $10 \%$ of households remain untitled after four years of program operation for (unobservable) reasons other than insufficient years of residence. 
In the realm of literature on the economic benefits of tenure security, the Peruvian experience constitutes a unique natural experiment in terms of providing cost-free improvements in ownership security on a national scale.

\section{CONCEPtual Framework}

In practice, tenure insecurity in Peru encompasses both fear of eviction by the government and fear of property theft by other residents. In a recent nationwide survey of Peruvian households, only $33 \%$ without title felt very certain that their land would not be invaded by other residents, and only $34 \%$ felt very certain that they would not be evicted (IADB 2004). ${ }^{9}$ There are two principal mechanisms by which such concerns potentially remove individuals from the labor force. First, since it is costlier for informal residents to rely on law enforcement or judicial systems to resolve disputes, they have greater incentive to provide informal policing through individual and community efforts in order to deter prospective invaders from encroaching on or robbing individual properties. ${ }^{10}$ Even if land takings are uncommon, households may be willing to expend significant resources preventing property disputes given that they have no legal recourse. In the baseline data, $19 \%$ of households report the existence of community organizations to protect property prior to the titling program. ${ }^{11}$ Similar institutions were common in nineteenth century California, where squatters reportedly spent considerable time protecting property boundaries in organized Squatters Leagues (Clay 2006). Given that commuting times of an hour or more are relatively common among titled households in this analysis (31\%), it is plausible that participation in community policing efforts could substantially hinder labor market opportunities. ${ }^{12}$ Furthermore,

9. Excessive fear of land takings by the government may have roots in a feature of Incan land policy that became a major political problem in the last days of the empire: Under Incan law, government lands were treated as private lands of the ruler to be passed on to his descendents other than his successor. Therefore, whenever a new leader took power, he was forced to seize new lands in each province in order to provide an estate to support the new government (Rowe 1960).

10. Untitled individuals are likely to feel more threatened by robbery, given that those without legal rights to a residence generally have less legal claim to property inside the home.

11. Source: Baseline Survey (Instituto Cuánto 2000), author's tabulations. Households that participated in the titling program were asked about the existence of community organizations currently as well as before the program.

12. Source: Baseline Survey (Instituto Cuánto 2000), author's tabulations. 
if prospective squatters seek out abandoned land, individuals may be able to deter conflicts over property boundaries or robbery simply by staying close to home to signal that property is occupied. In total, $47 \%$ of untitled households report keeping someone at home for property protection, consistent with anecdotal evidence such as the following quotation from a squatter in Lima prior to the program: ${ }^{13}$

"I go to work, and my mother looks after the house," says Alejandrina Matos Franco, who sells cassettes on the street in Lima and who worries that people could seize her house when she is away (Conger 1999).

Second, reducing the probability of government eviction at the community level may require a critical mass of individuals squatting on neighborhood land, particularly in early stages of community formation. As a result, social norms may evolve in which community members impose sanctions on households that do not stay close to their land. In informal settlements, there is significant scope for punishment by community members, since access to land and local public goods is governed internally. ${ }^{14}$

The influence of changes in tenure security on household labor supply can be captured in a simple variation of the basic agricultural household model. Here I outline the analytical framework, while details of the model and its underlying assumptions are provided in Field (2003). In this setup, household members' labor hours are divided between work in the outside market $\left(H_{o}\right)$, work at home $\left(H_{h}\right)$, and leisure $(L)$. Home security $(s)$ is a positive function of formal and informal property rights $(\theta$ and $\tau$, respectively) and total time spent at home $\left(Z=H_{h}+L\right)$. Household utility, given a set of characteristics $\psi$ and a resource endowment $E$, is assumed to be an increasing function of per capita leisure $(l)$, per capita consumption $(x)$, and home security:

$$
\mathbb{U}(x, l, s ; \psi, \mathbb{E}) \text {, where } s=s(\mathbb{Z}, \theta, \tau) .
$$

A key assumption is incomplete substitution between market goods and home security, as would be the case, for instance, if there were risk involved in employing nonmembers to guard property or nonmembers were incapable of protecting against government

13. Source: Baseline Survey (Instituto Cuánto 2000), author's tabulations.

14. Additionally, households may attempt to increase tenure security by going through time-intensive administrative steps necessary to acquire official land rights, but this is presumed to impose minimal time burden. 
eviction. ${ }^{15}$ In that case, households' ability to increase security by staying close to home implies that the optimal allocation of hours across home and market will depend on formal tenure rights. In particular, maximizing the above utility function subject to basic time and budget constraints yields the following inequalities:

$$
\frac{\partial H_{h}}{\partial \theta}<0 \quad \text { and } \quad \frac{\partial H_{o}}{\partial \theta}>0 .
$$

These conditions imply that, in aggregate, strengthening formal property rights decreases work hours inside the home and increases time spent working outside, reflecting the fact that an exogenous increase in formal property rights will decrease a household's need to spend time on property protection, thereby lowering the opportunity cost of outside labor. In addition, two auxiliary implications follow from this model: The effect of formal property rights on labor supply will be decreasing in the household's level of informal property rights, $\tau$, and in the number of working-age household members, $N$. The role of family size reflects the fact that the more individuals are living in a household, the more likely it is that someone stays at home at a given time regardless of security considerations. Similarly, work decisions of households with strong de facto rights are less distorted by the need to watch over the residence. These two predictions are tested empirically by analyzing whether the labor supply effects of acquiring a property title are larger for households with fewer members and fewer years of community membership.

An extension to the model considers the possibility that adults have a comparative advantage in security provision, which leads children to substitute for adults in the labor market when tenure security is low. In this case, while total household labor rises with an increase in formal rights, child labor hours will generally fall. ${ }^{16}$ This prediction is tested by analyzing the effect of tenure security improvements on the allocation of labor across children and adults.

While the theoretical model deals with changes in labor supply at a fixed wage rate, the empirical model will capture changes in actual employment levels, which are functions of both supply

15. Consistent with this, no one in the analysis sample reports hiring home security guards. Source: Baseline Survey (Instituto Cuánto 2000), author's tabulations.

16. Income effects from relaxing the household time constraint provide an alternative channel, since a reduction in child labor would also follow from the luxury and substitution axioms of Basu and Van's (1998) model of child labor. 
and demand. Given the number of households affected by the reforms, labor supply responses to the program could alter equilibrium wages. Since equilibrium wage effects would bias the estimated program effect on employment downward as long as leisure was a normal good, they are ignored in this analysis.

\section{Data and Estimation Methods}

\section{IV.A. Data Sets}

The empirical analysis makes use of a survey of 2,750 urban households conducted in March 2000 as part of the government program evaluation. ${ }^{17}$ The sample was drawn randomly from the universe of all target households for eventual program intervention based on the universe of residences in the 1993 census living in three categories of informal (administratively defined) population centers of the eight program cities (INEI 1993). The survey was stratified by city, with clusters of ten households randomly sampled at the census tract (henceforth neighborhood) level within cities, and the number of clusters was proportionate to the city target population. ${ }^{18}$ The survey instrument contains a wide range of information on household and individual characteristics, in addition to households' experiences with property formalization, current level of tenure security, and change in security associated with obtaining a land title.

Importantly, 355 households in the 2000 sample can be linked to records from the 1997 World Bank Living Standards Measurement Survey (Instituto Cuánto 1997), creating a small panel data set that spans the period over which the majority of program activity took place. ${ }^{19}$ Of these, 261 reside in neighborhoods that were titled after June 1997.

\section{IV.B. Identification Strategy}

To study the impact of receiving a property title on household labor, I exploit neighborhood-level variation in the year in which

17. In total, 99 households were dropped from the analysis due to missing labor supply information for one or more members, 31 had missing data on property size and/or local elementary school facilities, 20 were in clusters in which there were no data on program timing, and in 8 all members were over the age of 80 , leaving 2,592 observations in the final sample.

18. Census tracts ("conglomerados") are population-based divisions of approximately 100 households, so the sample contains roughly $10 \%$ of households in a neighborhood.

19. The COFOPRI baseline included all households in the 1997 LSMS that were sampled in the target population (Apoyo Consultoría 2000). 
the titling program began. Because the survey was conducted midway through the program, the data contain a number of households in neighborhoods in which titling efforts had not yet begun. Administrative records on dates of program activity by neighborhood are used to identify whether neighborhoods were reached before or after the survey, henceforth "treated" or "untreated."20 Since not every squatter household in an early neighborhood had a title by the time of the survey, I employ an intent-to-treat (ITT) analysis in which all households living in early neighborhoods are considered treated. ${ }^{21}$ Appendix I gives a breakdown of households by city and treatment.

In an ITT framework, the measured program effect should increase mechanically with the fraction of households that receive titles. Since this fraction increases steadily over time, I also make use of variation among the treated in the year in which the program entered. For this purpose, program effects were restricted to be linear in four program years: January 1999-January 2000, January 1998-December 1998, January 1997-December 1997, and January 1996-December 1996. Furthermore, household labor supply may take time to adjust and confidence in the value of a title may grow over time.

An important advantage of these data is that all sample members live in areas that were targeted for intervention, reducing concerns over program placement bias. Nonetheless, there is still potential for program timing bias, in which areas selected for early program participation are systematically different with respect to the outcomes of interest. The influence of nonrandom city timing is addressed with a fixed effects regression model that compares titled and untitled households within cities, detailed in the proceeding section. ${ }^{22}$ A more complicated source of bias concerns

20. The COFOPRI Office provided dates on which the ownership verification process began. On average titles would not have been granted to residents for an additional three to five months. For this reason, neighborhoods are only considered titled in the analysis if verification activities begin prior to January 2000 . Administrative data were available only at the level of population center, which vary from 50 to 500 households. Because the sampling scheme ignored these divisions, households in a single neighborhood typically but not always fall into the same population center ( $68 \%$ fell into one, $27 \%$ fell into 2 , and $5 \%$ fell into 3 ).

21. Households in treated neighborhoods may not have a title for the following reasons: they cannot prove residence prior to 1995; they belong to a cooperative association; the residence lies on an archeological site, flood plane, mining site, or private property; or their ownership claims are disputed. According to one program administrator, disputes within families or between neighbors were the most common reason that title distribution was delayed (Gandolfo 2000).

22. A World Bank project report (2000) states that order of cities was designated in advance according to "ease of entry," but specifies no guidelines for 


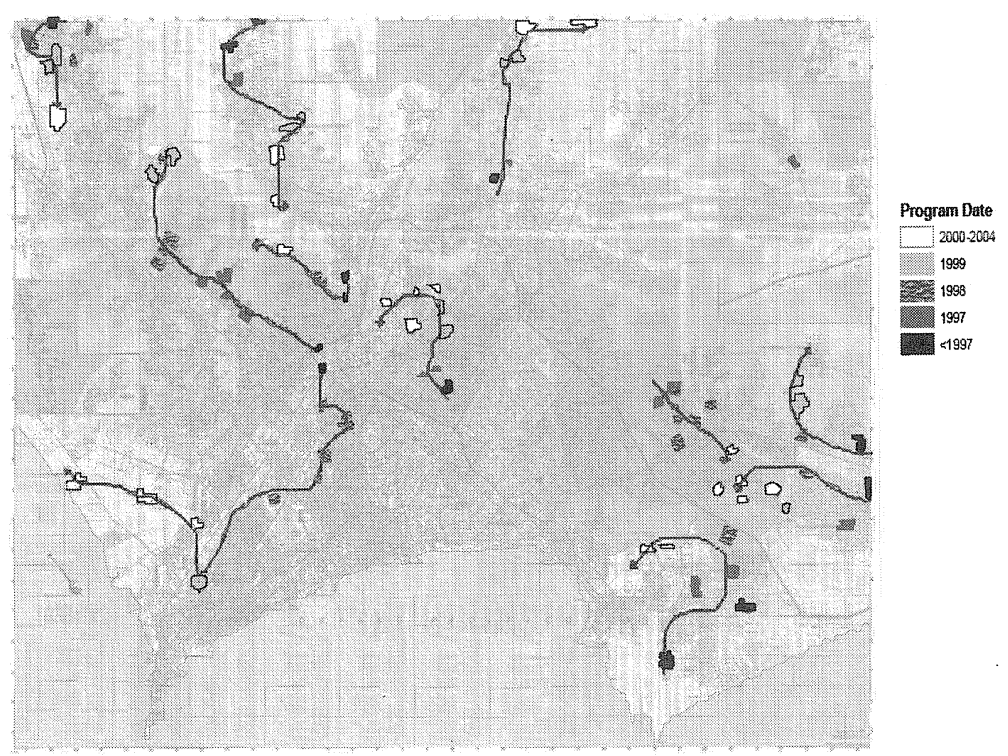

Figure I

Timing of Program Entry across Metropolitan Lima

Notes. Metropolitan Lima. Each colored block represents a population center (one of three official categories: human settlement, informal urban neighborhood, and "urbanizacion popular," administrative divisions that vary in size from 50 to 500 households). Program dates, compiled by the COFOPRI office in 2004 upon request of the author, reflect the specific day on which activities began in 88 neighborhoods of Lima, 70 of which were sampled in the COFOPRI Baseline Survey (Instituto Cuánto 2000). Sizes and shapes of population centers are approximations based on boundaries of varying specificity on underlying street map.

the order in which project teams entered neighborhoods within cities, about which there is little concrete information. According to project documents, project teams were assigned to starting points in the city and instructed to move contiguously through a district until all eligible neighborhoods were covered (COFOPRI 2000).

Figure I plots the spatial distribution of 85 neighborhoods sampled from metropolitan Lima, shaded according to timing of program entry. The figure reveals specific paths of program activity originating in several areas of the city. For instance, from the upper left corner of the map in the Northern Cone of the

neighborhood timing. One outside report claims order was subject to "geographical situation, feasibility, .... dwellers' requests, existing legal and technical documents, and linkages with other institutions" (Yi Yang 1999). 
city, program officials moved southward toward the city center through the districts of Comas and Rimac. Similarly, project activity moved west along the Rimac River through the district of Ate and moved east from the city center in Lima district toward the coastal districts of Callao. Although the patterns of movement are less clear in the southern part of the city, it is still possible to identify paths of program activity within districts based on clusters of neighborhoods that were reached at similar points in time. The map reveals two important details of program activity: First, activity indeed appears to have begun at several different points in the city and moved into contiguous neighborhoods over time. Second, because program teams moved in different directions and at different speeds, there is no clear pattern of movement according to neighborhood socioeconomic status or centrality. In each program year, neighborhoods are reached in all parts of the city.

The second point is evident in a comparison of sample characteristics across early and late neighborhoods. The observed similarity between program and nonprogram neighborhoods across a wide range of measures prior to the reforms provides empirical evidence against the most obvious sources of endogenous program timing: those related to community wealth and political leaning. Table I reports eight district-level poverty indicators from the Peruvian Ministry of Economics and Finance, based on 1993 census data: rates of chronic malnutrition, illiteracy, fraction of school-aged children not in school, residential crowding, adequacy of roofing, and the proportion of the population without access to water, sewerage, and electricity. ${ }^{23}$ Not only does it appear that early and late neighborhoods are evenly distributed across districts of varying poverty indices, but the differences in all eight base indicators are small and insignificant and inconsistent in sign. Also reported is the district-level fraction of votes for candidates affiliated with the ruling party, "Vamos Vecino," in the

23. For a detailed description of the FONCODES indicator, see Schady (2002) and notes to Table I. A municipal district is an administrative boundary set forth by the national government that varies in size and population. In total, there are 45 districts in the sample, 37 of which have district-level voting data (district-level voting data are unavailable for the nine province capitals, since municipal councils in province capitals are elected by the entire province). Neighborhoods are population-based subsets of districts. On average a district comprises 200 neighborhoods, and a mean of 6 neighborhoods were sampled per district. Means in Table I are weighted to account for variation across cities in fraction of districts that are treated. 
TABLE I

PRE-PROGRAM District CHARACTERISTICS

\begin{tabular}{|c|c|c|c|}
\hline & $\begin{array}{c}(1) \\
\text { No program }\end{array}$ & $\begin{array}{c}(2) \\
\text { Program }\end{array}$ & $\begin{array}{l}(3) \\
t_{\Delta}\end{array}$ \\
\hline \multicolumn{4}{|l|}{ FONCODES Poverty Indicators, 1993} \\
\hline Proportion of population without access to water & 33.87 & 31.71 & 0.56 \\
\hline Rate of inadequate roofing & 38.61 & 37.73 & 0.21 \\
\hline $\begin{array}{l}\text { Proportion of population without access to } \\
\text { electricity }\end{array}$ & 21.36 & 19.10 & 0.81 \\
\hline $\begin{array}{l}\text { Proportion of population without access to } \\
\text { sewerage }\end{array}$ & 33.40 & 35.36 & -0.58 \\
\hline Rate of school-aged children not in school & 6.34 & 6.21 & 0.52 \\
\hline Rate of illiteracy & 5.58 & 5.95 & -0.75 \\
\hline Rate of residential crowding & 17.47 & 16.94 & 0.45 \\
\hline Rate of chronic malnutrition & 25.95 & 25.04 & 0.70 \\
\hline Composite poverty index & 11.03 & 10.94 & 0.10 \\
\hline \multicolumn{4}{|l|}{ Municipal Election Votes, 1998} \\
\hline $\begin{array}{l}\text { Fraction votes for candidate from presidential } \\
\text { party }\end{array}$ & 0.272 & 0.278 & -0.23 \\
\hline Observations (neighborhoods) & 177 & 92 & \\
\hline
\end{tabular}

Notes: Raw means. All data at the neighborhood level (primary sampling unit). Observations weighted to equate distribution of program and non-program neighborhoods across cities. Poverty data come from the Peruvian Social Fund (FONCODES), administered by the Ministry of Economics and Finance. All indicators except rate of chronic malnutrition estimated with 1993 population census data; rate of chronic malnutrition estimated from a census of height and weight among school-aged children conducted by FONCODES in 1993. Compite index created by dividing ach indicator by its minimum value, multiplying rate of chronic 1993. Composite index created by dividing each ind malnutrition by seven, then adding all individual indicators and dividing by the lowest value. Index ranges from 1 to 36.38 and is increasing in the rate of povional Election Office. Presidential party is "Movimiento Independente Vamos Vecino", the pro-Fujimori electoral alliance. A municipal district is an administrative boundary set forth by the national government that varies in size and population. On average a district comprises 200 neighborhoods, and there are 45 districts in the data.

1998 municipal elections. ${ }^{24}$ From these data, there is no indication that program timing was determined by political leaning. The data are less than ideal given that much of the variation in program activity is within district and so should be interpreted with caution. However, 1997 LSMS data, which can be divided by neighborhood, also indicate that early and late neighborhoods

24. The "Movimiento Independente Vamos Vecino" was founded by President Alberto Fujimori in 1998, and later became Frente Peru 2000. The antecedent party was Cambio 90/Nuevo Mayoria. In Peruvian municipal elections, voters cast ballots for mayors and councils of district-level municipalities. According to Schmidt (2004), "Although Fujimori's reelections in 1995 and especially 2000 were controversial processes, the outcomes of municipal elections in the 1990s were broadly accepted by Peruvians of diverse political tendencies. Opposition and local lists won more races than the president's supporters, and allegations of fraud were limited to specific localities." 
were similar across a range of characteristics, including the outcomes of interest, prior to the program (Table II).

Nonetheless, without precise knowledge of the determinants of neighborhood timing, I cannot safely assume random assignment nor accurately specify a selection-on-observables model. Hence my cross-section identification strategy makes use of a comparison group of nonbeneficiary households to estimate an empirical model that is robust to some degree of selection on unobservables. In a framework analogous to difference-in-difference (DID) estimation, I compare the difference in labor supply of potential program beneficiary and nonbeneficiary households in early neighborhoods to the difference between beneficiaries and nonbeneficiaries in late neighborhoods. To classify beneficiaries, I make use of detailed survey data on past and present property titles to construct a binary indicator of whether a household had a registered title at the time the program entered their neighborhood. Those that did not are labeled squatters, while the term nonsquatter refers to households that were titled prior to the program. ${ }^{25}$ The simple idea underlying this distinction is that the change in tenure security from titling disproportionately benefits households with weak ex ante property claims.

There were several ways a household might have obtained a property title in the era before the recent titling effort. First, there was the lengthy and costly option of following the official bureaucratic process for obtaining and registering a municipal property title from inheritance claims, sales documents, or possession claims. Second, there were a handful of past isolated attempts at property reform in which interim titling agencies were set up by municipal governments in an effort to incorporate informal residents (De Soto 1990). Finally, on a number of occasions, mayoral and presidential candidates were known to distribute property titles in an effort to win voter support prior to an election (Yi Yang 1999). Although valuable, these efforts provided only a foot in the door for obtaining complete ownership rights, since it remained up to individuals to go through the lengthy and costly registration process that would fully protect them against future claims.

Columns (4)-(10) of Table II provide descriptive statistics for the cross-section sample, allowing an informal check of

25. Households are considered nonsquatters if they possessed any registered property title, or an unregistered municipal or sales title at the time of program entry. In the remainder of the paper, "squatter" refers to households without titles before the program. 
URBAN PROPERTY RIGHTS AND LABOR SUPPLY IN PERU 1575

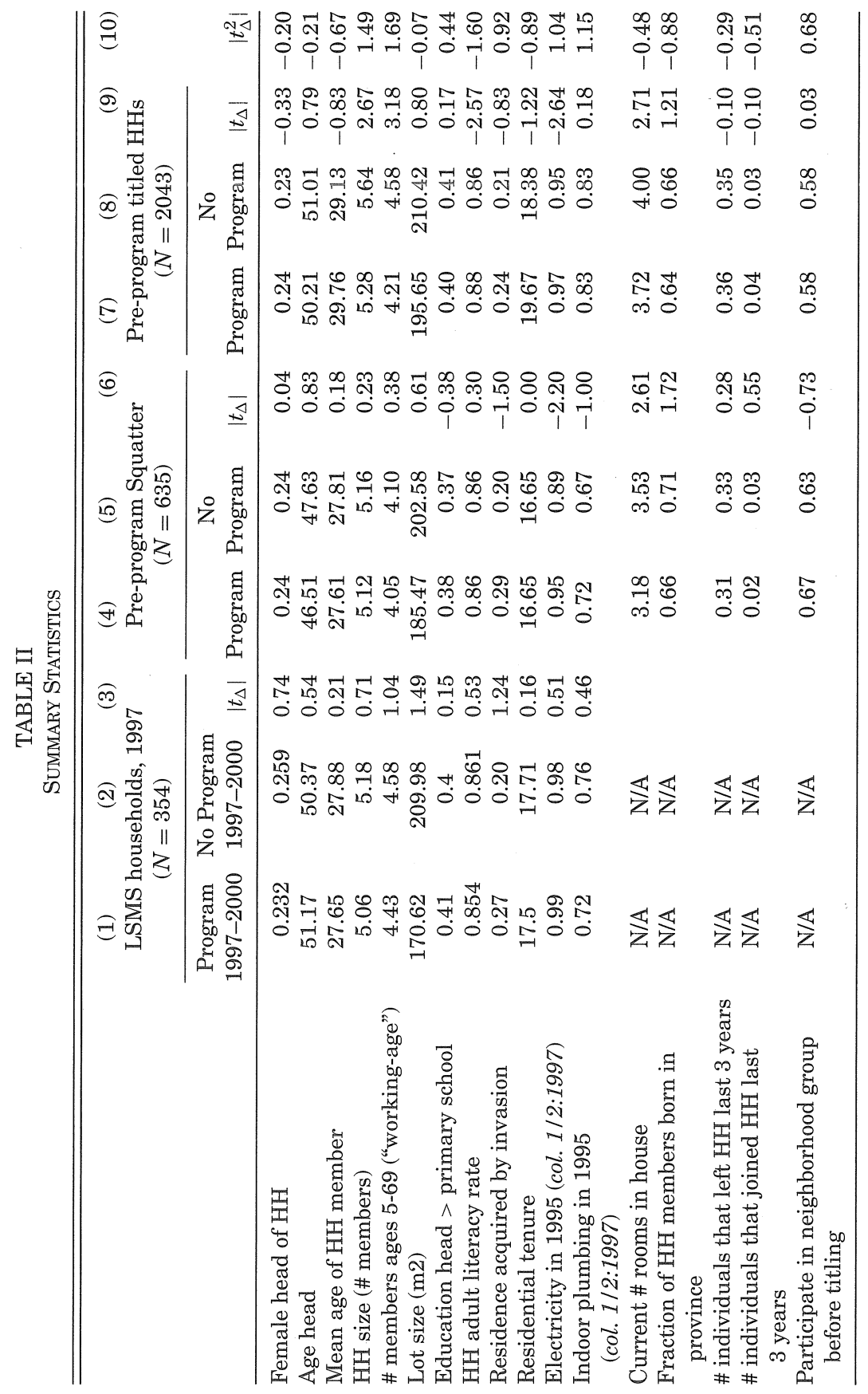




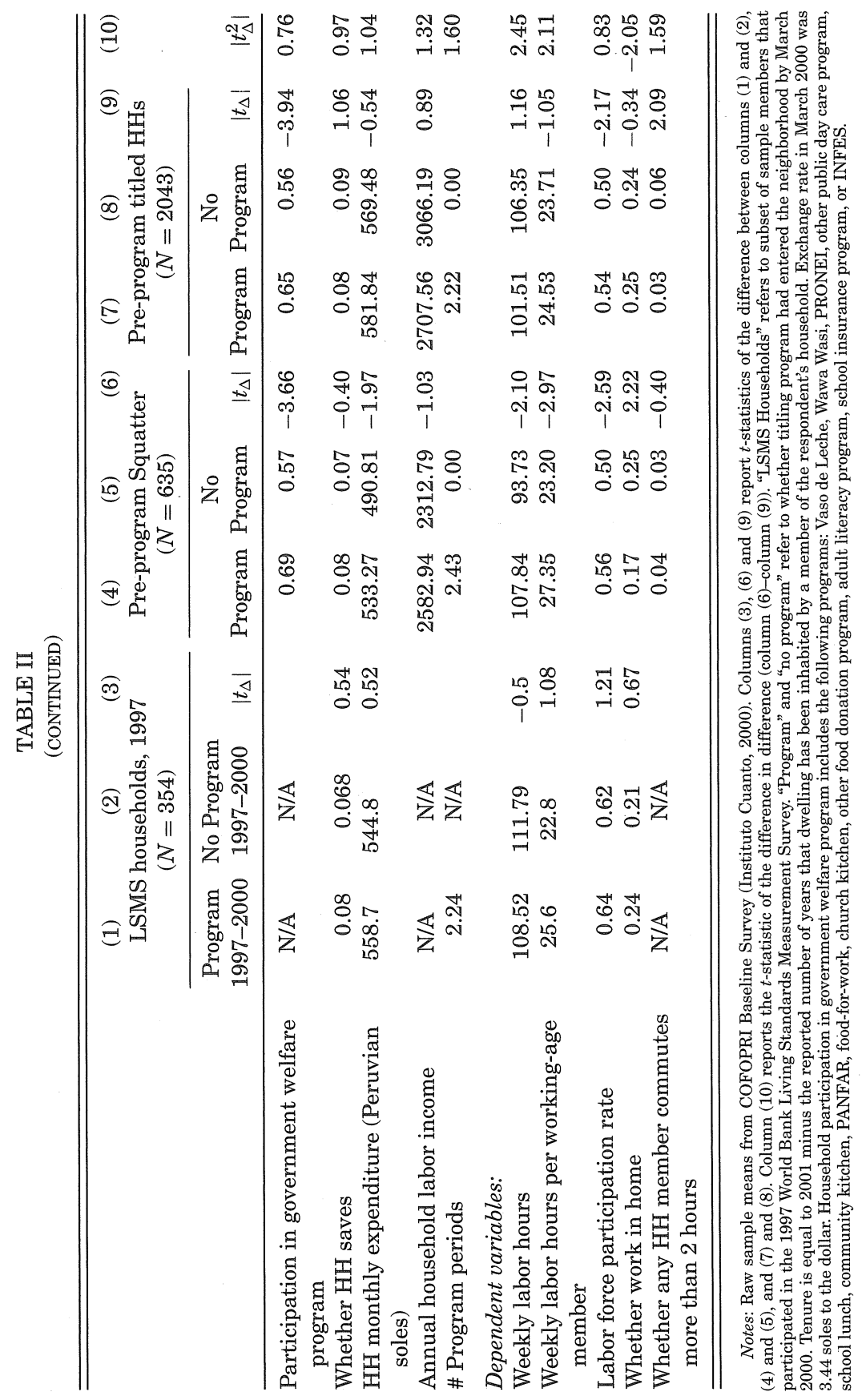


quasi-random assignment of program timing. Observations are weighted to balance the distribution of comparison groups across cities. As the means in the table indicate, there is little variation in demographic characteristics across program and nonprogram areas. Furthermore, no statistically significant differences in differences are observed between squatters and nonsquatters in program and nonprogram areas (column (10)), which supports the use of nonsquatters as a comparison group. Among the available observables, comparable participation rates in community collective action are particularly revealing, since collective action data from titled households refer to the period before titling began. Although squatters on average are more likely to participate in government welfare programs than nonsquatters, comparable participation rates of each group across areas indicates similar poverty profiles in early and late neighborhoods. ${ }^{26}$ Although differences in monthly consumption between squatters in program and nonprogram areas are marginally significant, this is also consistent with a change in labor supply among the former. A similar pattern is observed when raw sample means are compared across squatters and nonsquatters in early program periods according to year of entry, detailed in Appendix II. Although there are some observable differences between neighborhoods that were reached in 1996 and 1997 and those reached in 1998 and 1999, differences between squatters and nonsquatters are consistently independent of program timing.

While the labor supply of squatters may differ systematically from that of nonsquatters due to any number of unobservable factors, identification of program effect will be robust as long as this difference is constant across program and nonprogram neighborhoods. To address the possibility that it is not, I take three additional steps. First, I control for a large set of observable household and neighborhood characteristics. Second, I exploit two sources of predicted variation in the impact of titling on different households types. In the model of Section III, the impact of receiving a title is predicted to decrease in both household size and level of informal property rights. In the empirical analysis, I use residential tenure as a proxy for informal property rights based

\footnotetext{
26. Household participation in government welfare program includes the following programs targeted to households below the poverty line: Vaso de Leche, Wawa Wasi, PRONEI, other public day care program, school lunch, community kitchen, PANFAR, food-for-work, church kitchen, other food donation program, adult literacy program, school insurance program, or INFES.
} 
on evidence that households with longer community membership are able to rely more heavily on community enforcement of informal rights (De Soto 1990; Lanjouw and Levy 2002). Because both household size and residential tenure are highly correlated with poverty but in opposite directions, the dual restriction that program effect be increasing in household size and decreasing in residential tenure reduces concerns over program timing bias by eliminating the possible confounding role of unobservable trends correlated with poverty. ${ }^{27}$

Finally, I estimate an analogous regression model using the subsample of households that can be linked to the 1997 household survey, in which the dependent variable is the change in labor force activity between 1997 and 2000. ${ }^{28}$ The sample is again divided into households in neighborhoods titled between 1997 and 2000 and households reached post-2000 and between program beneficiaries and nonbeneficiaries. This allows me to test a key assumption underlying the interpretation of cross-section difference-indifference results - that the results reflect a recent change in labor supply unique to newly titled households rather than preexisting differences between squatters and nonsquatters in program and nonprogram areas. Identification in the panel regression model no longer requires that squatters and nonsquatters have similar behavior across program and nonprogram regions; the program effect is consistently identified as long as differential time trends in labor supply of squatters relative to nonsquatters are constant across program and nonprogram regions, a significantly less stringent assumption than the baseline DID model.

\section{IV.C. Regression Model}

The basic estimate of program effect is obtained from the OLS regression

$$
\begin{aligned}
L_{i j k}=\beta_{0} & +\beta_{1}\left(N_{i j k}\right)+\beta_{2}\left(N_{i j k}\right)^{2}+\beta_{3}\left(\text { squatter }_{i j k}\right) \\
+ & \beta_{4}\left(\text { program }_{j k}\right)+\beta_{5}\left(\text { program }_{j k} \cdot \text { squatter }_{i j k}\right) \\
& +\Pi^{\prime} X_{i j k}+\Omega^{\prime} Z_{j k}+\varphi\left(C_{k}\right)+\gamma\left(C_{k} \cdot \text { squatter }_{i j k}\right) \\
& +\phi\left(C_{k} \cdot \text { program }_{j k}\right)+e_{i j k}
\end{aligned}
$$

27. Correlations between poverty indices and both household size and length of residence verify these patterns in the analysis sample.

28 . In total, 98 households that were reached in 1996, and the first six months of 1997 were excluded from the panel sample. 
where $L_{i}$ refers to weekly labor hours of household $i$ in neighborhood $j$ and city $k ; N$ is number of household members; squatter refers to a household with no preprogram property title; program indicates whether neighborhood $j$ has been reached by the program; $X_{i j k}$ is a vector of demographic controls; and $Z_{j k}$ is a vector of neighborhood-level controls. The outcome variable is the sum of all household members' weekly employment hours, constructed from survey questions on number of days and mean hours per day worked last week asked of all household members who report having worked during the past week. ${ }^{29}$ The coefficient on the interaction between program and squatter, $\beta_{5}$, is the estimated program effect, which provides a measure of the conditional average difference in time worked by squatters in program areas.

To remove the influence of endogenous city timing, all regressions throughout the analysis include city fixed effects, $\varphi$, as well as interactions between cities and program entry $\left(C_{k} *\right.$ program $)$ and between cities and preprogram tenure status $\left(C_{k}{ }^{*}\right.$ squatter $)$. In this manner, each regression controls not only for differences across cities in mean labor supply, but also for differences across cities in the mean labor supply of squatters relative to nonsquatters and of households in program neighborhoods relative to households in nonprogram areas. The inclusion of these interaction terms absorbs potential regional variation in program implementation and regional differences in informal property institutions that could otherwise generate relative differences in program impact between titled and untitled residents.

The following demographic controls are included in $X$ : number of household members aged 5 to 69 , lot size $\left(\mathrm{m}^{2}\right)$, residential tenure, number of household members, number of children, fraction of adults that are male, fraction that migrated to the province, and number of members above age 69; sex, age, literacy and degree level of household head; whether household had indoor plumbing in 1995, whether property was acquired by invasion, whether property was inherited; and walking distance to nearest primary school, secondary school, bus stop, public phone, and public market. Neighborhood-level variables contained in $Z$ include whether neighborhood has bus stop, market, public phone, and primary and secondary school; and whether each of these existed two years

29. Working-age members who are not in the labor force and those who are in the labor force but report not having worked in the previous week are assigned employment hours values of zero. 
prior; and whether neighborhood has any of four categories of social programs (school, child, food, or general social assistance). It is arguable that the inclusion of such a wide set of demographic controls amounts to overcontrolling. However, all of the proceeding results are robust to the exclusion of all but the basic controls (tenure, household size, and lot size), and point estimates and significance differ little between unsaturated and fully saturated models. All estimates are adjusted to account for sample clusters and strata. The standard errors are derived from the HuberWhite robust estimator for the variance-covariance matrix.

Two extensions of the basic estimating equation further explore the heterogeneity and dynamics of the treatment effect by including interactions between program*squatter and household characteristics. The first extension interacts squatter with number of years since program entry (prog-periods), which picks up any differential patterns in labor supply of squatters relative to nonsquatters that may be correlated with the neighborhood's length of program exposure. ${ }^{30}$ This regression adds to equation (1) the following variables: prog_periods, prog_periods*squatter, and prog_periods*squatter*program. The second extension allows for additional variation by residential tenure and household size by interacting squatter with number of household members aged 5-69 $(N)$, number of household members squared $\left(N^{2}\right)$, and number of years that household $i$ has lived in the residence (tenure), which is used as a summary measure of household informal rights. Hence, this regression adds to equation (1) the following variables: $N^{*}$ squatter, $N^{*}$ program, $N^{*}$ squatter program, $N^{2 *}$ squatter, $N^{2 *}$ program, $N^{2 *}$ squatter* program, tenure* squatter, tenure* program, and tenure* squatter* program. The inclusion of a quadratic term in family size is driven by the assumption that leisure hours are correlated across household members, such that the likelihood that any member is at home at a given moment is increasing with family size at a decreasing rate.

The empirical analysis using panel data employs the same DID specification as the cross-section estimates, but regresses program participation on changes in the outcomes of interest between 1997 and 2000. In light of the dimensionality constraint imposed

30. The validity of the linear constraint on the program effect across entry year is tested by running unconstrained regressions for all outcome measures, presented in Appendix C of Field (2003). The coefficient estimates reveal a strikingly consistent trend of increasing program effect over number of periods since the program began, supporting the use of a linear restriction. 
by the limited amount of panel data, panel estimates focus only on variation in program response according to length of time since program entered:

(2)

$$
\begin{gathered}
\Delta L_{i j k}=\beta_{0}+\beta_{1}\left(\text { squatter }_{i j k}\right)+\beta_{2}\left(\text { program periods }_{j k}\right) \\
+\beta_{3}\left(\text { program periods }_{j k} \cdot \text { squatter }_{i j k}\right)+\beta_{4}\left(N_{i j k}\right) \\
+\beta_{5}\left(\Delta N_{i j k}\right)+\alpha_{1}^{\prime} X_{i j k}+\alpha_{2}^{\prime} \Delta X_{i j k}+\varphi\left(C_{k}\right) \\
\quad+\gamma\left(C_{k} \cdot \text { squatter }_{i j k}\right)+\phi\left(C_{k} \cdot \text { program }_{j k}\right)+e_{i j k} .
\end{gathered}
$$

Because time-invariant household and neighborhood characteristics are differenced out in this specification, regressions control only for number of members aged 5-69 in 1997 and change in number of members aged 5-69 between 1997 and 2000, property size in 1997 and change in property size between 1997 and 2000, number of children aged 5-16 in 1997 and change in number of children aged 5-16 between 1997 and 2000 .

\section{EMPIRICAL REsults}

\section{V.A. Program Effect on Tenure Security}

The model discussed in Section III predicts that obtaining a property title affects household labor supply by reducing a household's perceived probability of eviction. This first-stage relationship is verified by comparing raw means of the following survey indicators on perceptions of eviction risk across treatment groups: whether the household reported experiencing a change in tenure security with the acquisition of a property title, whether eviction is considered very likely, and whether eviction is considered very unlikely. According to the simple DID estimates reported in Table III, the data provide strong evidence of a first-stage program effect on security: $98 \%$ of squatters who were titled in program neighborhoods report experiencing a change in tenure security. Importantly, expectations of eviction are also consistent with the variations in program entry and groups of beneficiaries described in the previous section: recently titled squatters report eviction risk almost identical to households titled before the program, which is one-third the risk rate of squatters still awaiting title.

\section{V.B. Effect of Titling on Labor Supply}

Evidence of a corresponding program effect on labor supply comes from a visual comparison of preprogram squatter and 


\begin{tabular}{|c|c|c|c|c|c|}
\hline 582 & $Q U A$ & $A R T E R$ & OURNA & LOF ECONON & \\
\hline 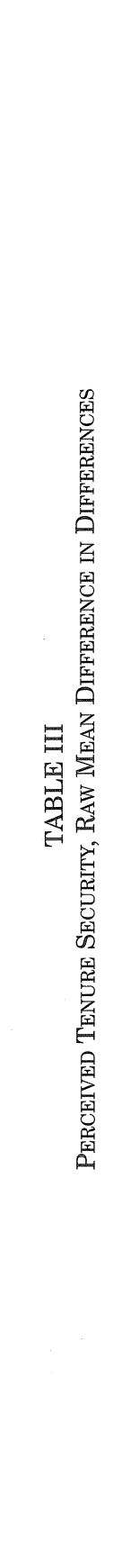 & 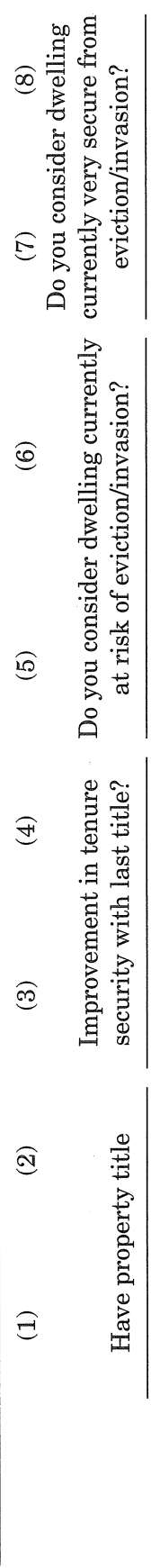 & 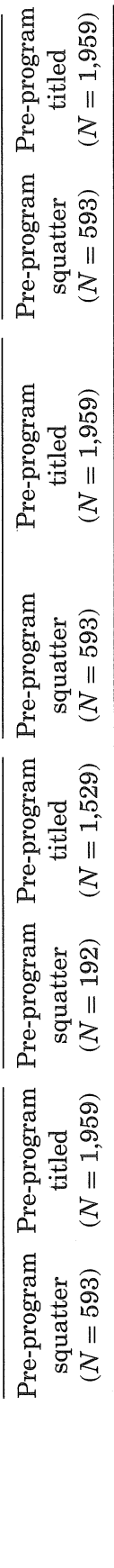 & 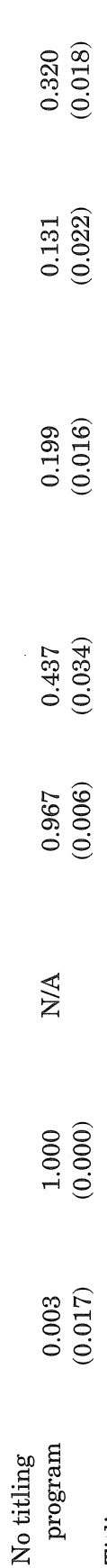 & 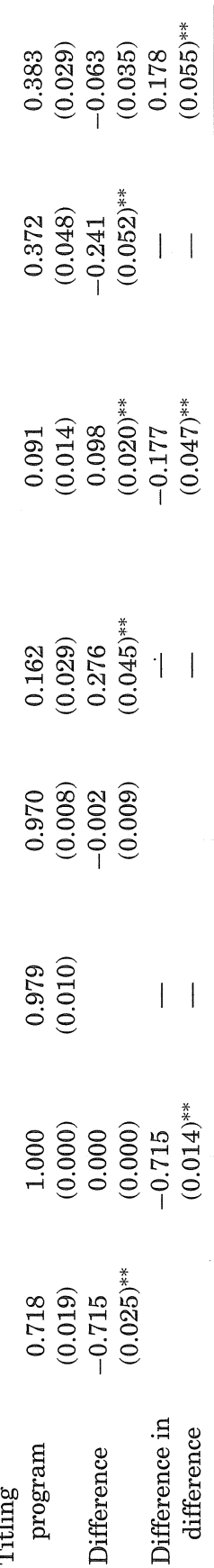 & 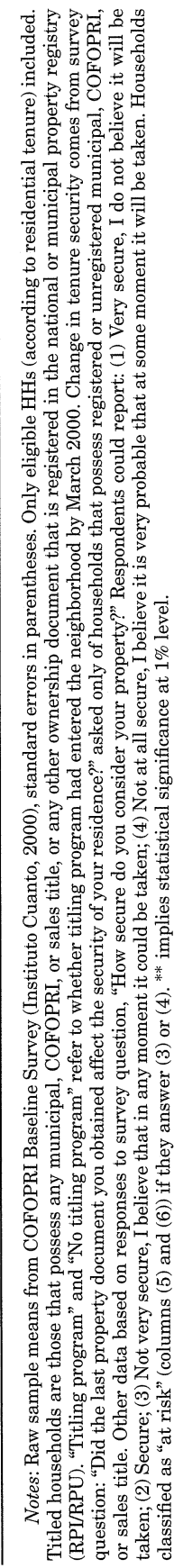 \\
\hline
\end{tabular}




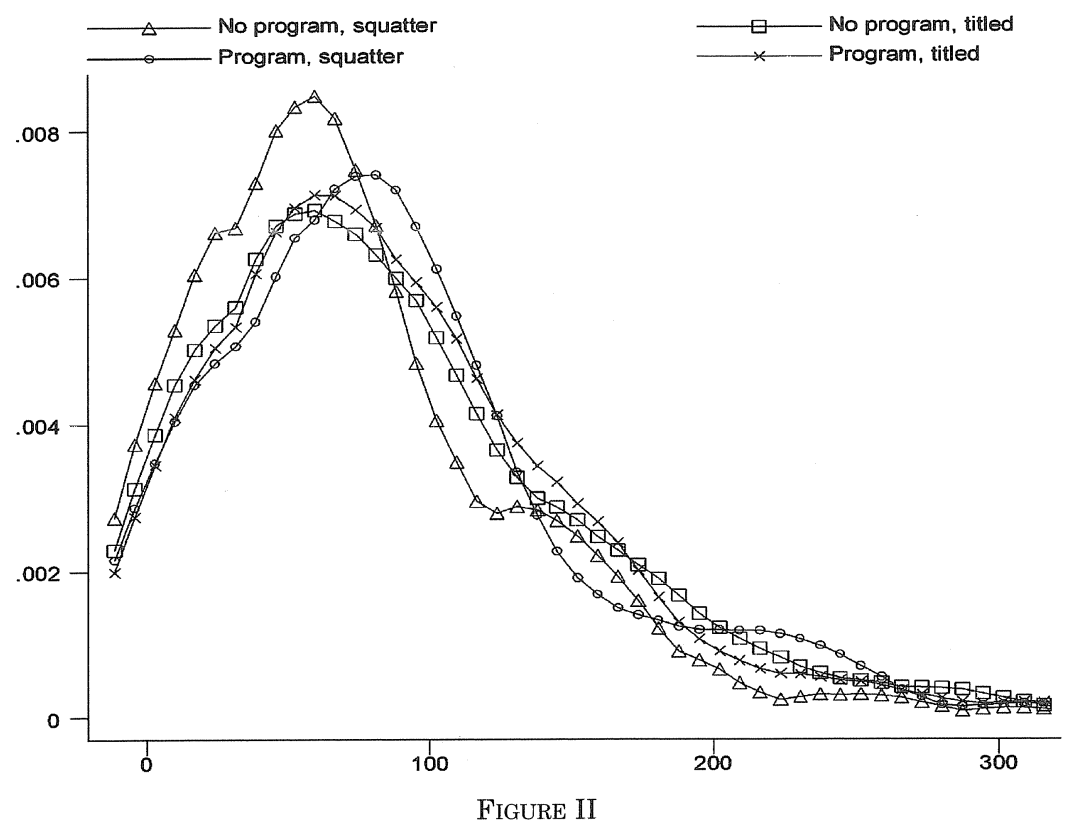

Kernel Density Estimates of Weekly Household Labor Hours

Notes. Weekly household labor hours are sum of all household members' weekly employment hours, constructed from number of days and mean hours per day worked last week. Estimates use Epanechnikov kernel function. "No program" refers to households living in neighborhoods in which the program has not entered, and "squatter" refers to households that did not possess a title prior to the program.

preprogram titled households in program and nonprogram neighborhoods. Figure II plots the distribution of weekly labor force hours per household in the four DID subsamples. Three important patterns emerge: First, the density marked by squares, which corresponds to squatters in neighborhoods not yet reached by the program, is visibly distinct from the densities corresponding to the two groups of residents in program areas and also from that of the titled residents in nonprogram areas. ${ }^{31}$ This pattern is consistent with a scenario in which the titling program generates a rightward shift in the distribution of squatters' work hours to reach that of title-holders. Second, the hours distribution of nonsquatters is relatively constant across program and nonprogram areas. Third, nonsquatters' work hours are also similar to the work hours of preprogram squatters after the program has

31. The distribution of squatters in program areas stochastically dominates that of squatters in nonprogram areas. 
entered. These regularities lend confidence to the use of nonsquatters as a comparison group.

This basic DID pattern is explored more closely by estimating the linear regression model detailed in the previous section. In columns (1)-(5) and (8)-(9) of Table IV, the dependent variable is total household weekly hours of paid and unpaid work, measured from reported employment of all household members during the seven days prior to the survey. In the first estimate, the marginal effect implied by.the estimated coefficient on the interaction term between squatter and program is 13.5 hours per week (column (1)), which corresponds to a $14 \%$ increase in total household labor supply. When the program effect is allowed to vary with years since the program began, the marginal effect implied by the estimated coefficient on the interaction term between squatter and program periods is 10.1 hours, while the fixed effect is -8.0 hours but is insignificant (column (2)). This implies a total program effect of 12.2 hours per week-or around one day of full-time work-for the median squatter household with two years of formal property rights. The implied program effect after four years is an increase of 32 hours of employment per week, or slightly less than one worker per squatter household being added to the labor force.

The estimates in which the program effect is allowed to vary with household size and length of residence indicate that more constrained households-those with greater security concerns and fewer potential workers-increase labor hours more in response to an increase in tenure security (column (3)). Allowing the program effect to vary by size and tenure also accounts for the negative main effect in column (2), as both the level and the dose effect of the program become significant and positive. The observed variation in program impact is notable, since it is consistent with the theoretical predictions but inconsistent with the most obvious competing explanations for the basic result. For instance, if squatter households in program areas work more because of better local job opportunities, this could either disproportionately benefit the poor, in which case the effect would be increasing rather than falling in household size, or disproportionately benefit squatters who are better off, in which case the effect would be rising rather than falling in household tenure.

A number of regressors are arguably correlated with tenure security through such behaviors as migration of household members, fertility and housing investment. However, as observed in columns (4) and (5), the results are robust to excluding all but the 
URBAN PROPERTY RIGHTS AND LABOR SUPPLY IN PERU 1585

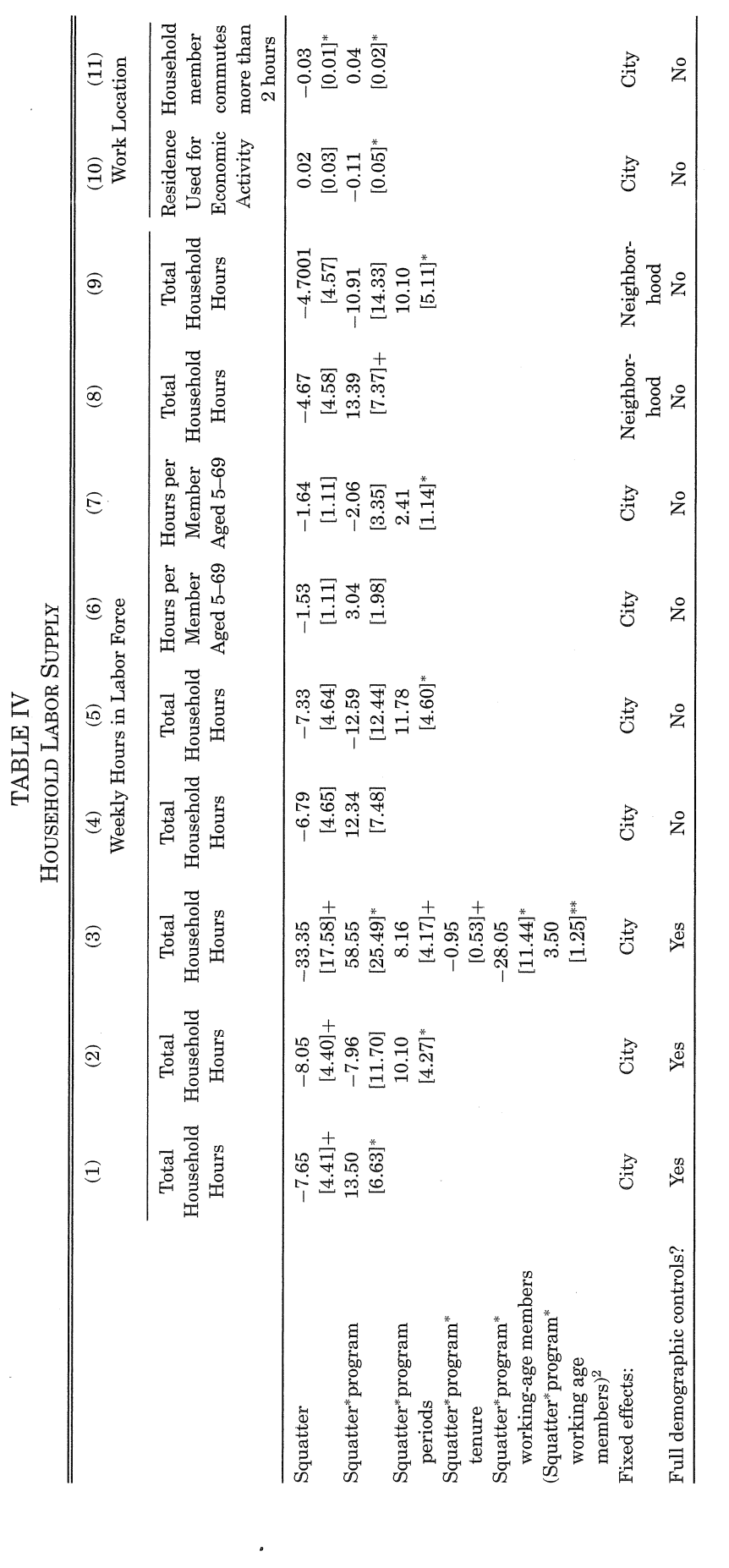




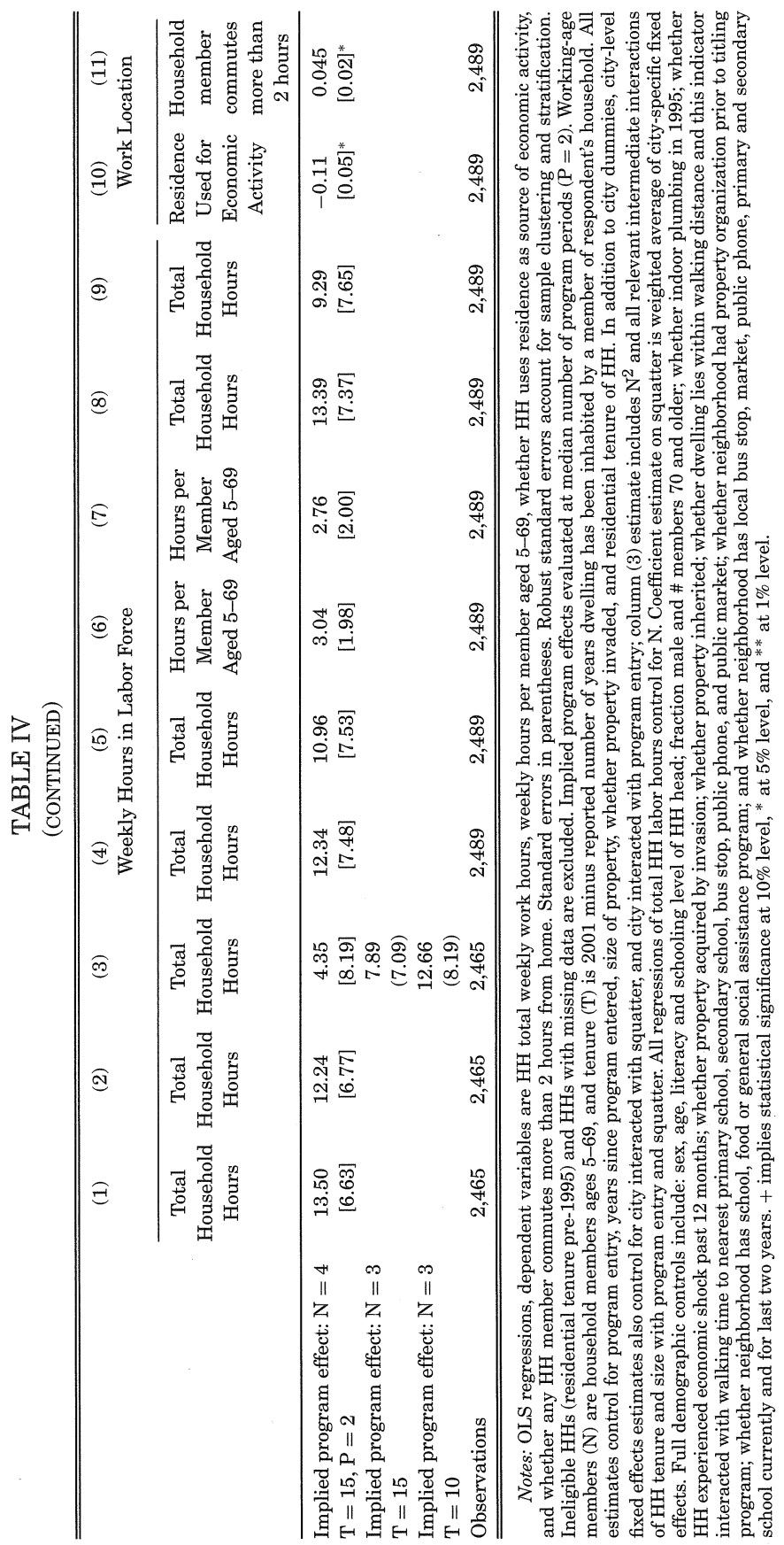


basic controls (years of residence, property size, members aged 5-69, and whether invaded), which provides general evidence against many potential sources of endogeneity bias. Similarly, the estimates change little when the dependent variable is replaced with hours per working-age member (columns (6) and (7)) or when neighborhood fixed effects are added to the regression model (columns (8) and (9)). In both the unsaturated and fixed effects regressions, the coefficient estimates are almost identical and the program effect remains significant. Although endogenous changes in household composition could still bias the estimates, summary statistics indicate no significant mean differences across treatment groups with respect to current household members' years of residence, rates of out-migration of past members, and three-year changes in household composition (Table II). Furthermore, replacing the dependent variable with head's labor hours produces the same pattern of results, which suggests that changes in household composition are not driving the results.

The regression estimates in columns (10) and (11) examine the effect of titling on work location. In the sample, $26 \%$ of households report running a business from the home or using part of their property as a source of economic activity. While a general class of models of household production treats labor supply decisions as separable from production decisions, in this context, in-home work has the additional feature of increasing tenure security and thereby reducing the household demand for leisure. Thus, in the absence of a property title, the model implies that the decision to run a business from the home is determined jointly with decisions about the total number of hours worked. If there is less of a security incentive to stay at home when formal property rights are secured, newly unconstrained decision-makers will have an incentive to allocate resources more efficiently by moving production outside of the home or finding work with an outside employer. The linear probability estimate of the effect of titling on market work at home supports this prediction: the implied marginal change in the likelihood of working inside the home falls by 11 percentage points for the average squatter family in a program neighborhood-implying a reduction in the rate of home business activity by $40.3 \%$. Similarly, the estimate in column (11) indicates a significant increase in the fraction of households in which a worker commutes more than two hours each way, distances that are likely to involve spending several days at a time away from home. 
Overall, the patterns in Table IV suggest large labor supply responses to tenure security. Not only do the estimates match the first-stage results on subjective improvements in security, but also they match theoretical predictions on the groups of households that should be uniquely affected. A number of specification tests lend further support to these estimates. Excluding cities in which the program had not yet entered or already finished (Huancayo and Arequipa) at the time of data collection has little effect on the estimates. ${ }^{32}$ Identical estimates run on the $9.3 \%$ of households that were ineligible for a title on account of having moved into their residences post-1995 reveal no measurable program effect, suggesting that differential time trends disproportionately affecting the vulnerable are not driving the results.

\section{V.C. Instrumental Variables Estimates}

The results in Table IV underestimate the average treatment effect of receiving a title because the rate of titling within a neighborhood increased over time. While $74.2 \%$ of squatters in treatment neighborhoods received a registered property title by the time of the survey, the inclusion of the remaining $25.8 \%$ of untitled households in treatment areas biases the estimated program effect downward.

A standard method of predicting the average treatment effect of a title is to use the program as an instrument for having a title. Columns (2) and (4) of Table V present instrumental variables (IV) estimates under two different assumptions, and the corresponding first-stage regressions are presented in Columns (1) and (3). The first estimate assumes that the program influence is concentrated exclusively among title recipients. Whereas the ITT program effect associated an increase of 13.5 hours per week with program intervention, rescaling by number of titles implies an average treatment effect of 18.0 employment hours per week. An arguable improvement is to assume that the program effect is concentrated only among those $81 \%$ of titled households that also report experiencing a change in tenure security with titling. Under this assumption, the Table IV estimate predicts that titling efforts that are successful in making people feel more secure will lead to an average labor supply gain of 23.3 hours per week.

32. In a regression analogous to that of Table IV, column (4), the mean program effect estimate is 12.61 with a standard error of 6.49 . 
URBAN PROPERTY RIGHTS AND LABOR SUPPLY IN PERU

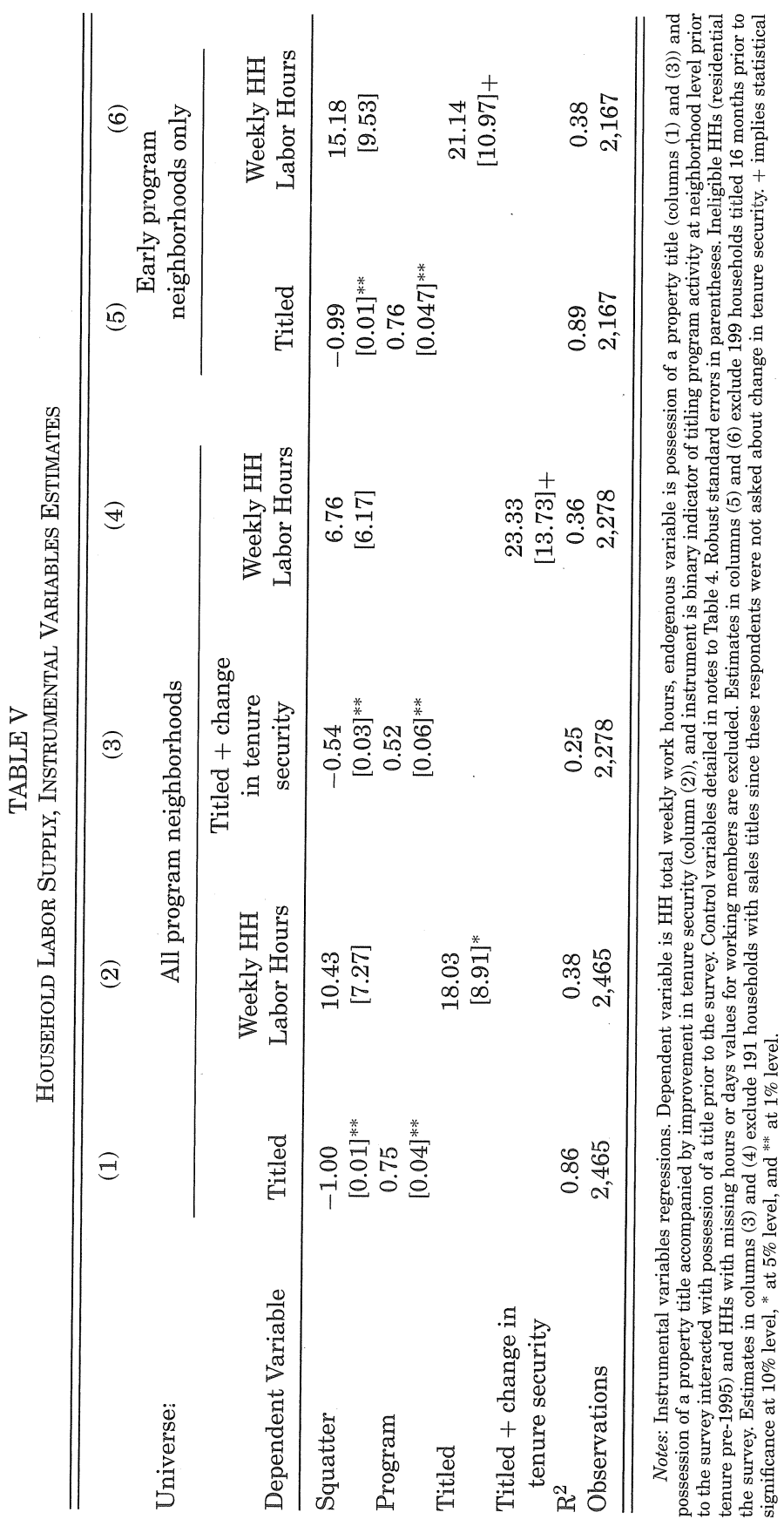


As mentioned previously, it is also possible that the impact of titling accumulates over time, either because households become increasingly convinced of the security value of a title or because they need sufficient opportunity to adjust their work behavior. In light of this possibility, the last estimate (column (6)) measures the program effect excluding the subpopulation of recent program neighborhoods, those in which the program entered within 16 months of the survey. The results imply an average increase in labor supply attributable to the program after at least 16 months of around 21.1 hours per week. This is considerably larger than the column (2) estimate, consistent with some degree of lag in program impact.

\section{V.D. Panel Estimates}

The regressions in Table VI use panel data available for 261 sample households that were titled after June 1997 to estimate the influence of program participation on the change in household labor supply before and after the program. The dependent variables are change in weekly work hours and work at home between 1997 and 2000. Panel estimates test the assumption that the DID results correspond to changes in the work behavior of squatters who were titled relative to nonsquatters and squatters who were not titled rather than pre-existing differences between squatters in early and late neighborhoods. If the causal interpretation of Table IV results is correct, the change in labor hours attributable to the program estimated with panel data should be comparable to the DID estimate of cross-sectional differences.

Indeed, the estimates in columns (1) and (2) of Table VI imply that households reached by the program prior to 2000 experienced an average increase in total work hours of 16-17 hours per week relative to households that were unaffected by the program. Similarly, program beneficiaries who did not work at home prior to the program were an estimated 15.8 percentage points less likely to begin using their residence as a source of economic activity (columns (3) and (4)). Among squatter households in nonprogram areas, $28 \%$ of households begin working at home over the period, which implies that households not reached by the program were twice as likely to start working at home.

Although the panel sample is too small to enable a detailed examination of household behavior, the similarity between the cross-section and panel estimates provides evidence in support of the DID identifying assumptions. In particular, the results 
URBAN PROPERTY RIGHTS AND LABOR SUPPLY IN PERU

TABLE VI

Changes in Household Work BeHaVior, 1997-2000

\begin{tabular}{|c|c|c|c|c|}
\hline \multirow[b]{3}{*}{$\begin{array}{l}\text { Change number } \\
\text { working-age members }\end{array}$} & \multirow{2}{*}{\multicolumn{2}{|c|}{$\begin{array}{l}\text { (1) } \\
\text { Change in total household } \\
\text { weekly labor hours }\end{array}$}} & \multirow{2}{*}{\multicolumn{2}{|c|}{$\begin{array}{l}\text { (3) } \\
\text { Begin using residence } \\
\text { for economic activity }\end{array}$}} \\
\hline & & & & \\
\hline & $\begin{array}{l}18.17 \\
(2.45)^{* *}\end{array}$ & $\begin{array}{l}17.83 \\
(2.45)^{* *}\end{array}$ & $\begin{array}{c}-0.001 \\
(0.021)\end{array}$ & $\begin{array}{r}-0.011 \\
(0.020)\end{array}$ \\
\hline Squatter & $\begin{array}{l}-15.60 \\
(7.18)^{*}\end{array}$ & $\begin{array}{l}-17.22 \\
(6.66)^{*}\end{array}$ & $\begin{array}{c}0.081 \\
(0.080)\end{array}$ & $\begin{array}{c}0.069 \\
(0.076)\end{array}$ \\
\hline Squatter*program periods & $\begin{array}{l}8.24 \\
(3.79)^{*}\end{array}$ & $\begin{array}{l}8.50 \\
(4.00)^{*}\end{array}$ & $\begin{array}{l}-0.088 \\
(0.037)^{*}\end{array}$ & $\begin{array}{l}-0.079 \\
(0.037)^{*}\end{array}$ \\
\hline $\begin{array}{l}\text { (4pt) Implied program effect } \\
\text { (program periods }=2)\end{array}$ & $\begin{array}{l}16.48 \\
(7.57)^{*}\end{array}$ & $\begin{array}{l}17.00 \\
(8.01)^{*}\end{array}$ & $\begin{array}{l}-0.176 \\
(0.075)^{*}\end{array}$ & $\begin{array}{l}-0.158 \\
(0.075)^{*}\end{array}$ \\
\hline $\begin{array}{l}\text { Interactions between squatter } \\
\text { and city and program } \\
\text { and city }\end{array}$ & no & yes & no & yes \\
\hline $\mathrm{N}$ & 257 & 257 & 195 & 195 \\
\hline
\end{tabular}

Notes: Panel data from sample of 355 respondents in 1997 LSMS re-surveyed in 2000 COFOPRI baseline survey; 98 households in neighborhoods reached prior to June 1997 excluded. Regressions in columns (3) and (4) exclude 62 households that worked at home in 1997. OLS regressions, dependent variables are change in household weekly work hours (columns (1) and (2)) and whether household bean using residence as of economic activity 1997-2000 (columns (3) and (4)). Robust standard errors in parentheses accout of ecount for sample clusters and strata. Implied program effects evaluated at median number of program periods (2). Panel spread across 89 neighborhoods in 5 cities. All regressions include controls for 1997 property size and change in property size 1997-2000, number members aged 5-69 in 1997 and change in number members aged 5-69 1997-2000, number children aged 5-16 in 1997 and change in number children aged 5-16 1997-2000, whether household in neighborhood reached by program in 1997, 1998, 1999, or after the survey (program periods), and binary indicator of city. Columns (2) and (4) also control for interactions between program entry and city, and squatter and city. * implies statistical significance at $5 \%$ level and ${ }^{* *}$ at $1 \%$ level.

suggest that cross-section estimates reflect recent changes in labor supply rather than pre-existing differences between program and nonprogram areas.

\section{V.E. Effect on Household Allocation of Labor}

Table VII decomposes the program effect in Table IV to study variation in the impact of titling across household members. Here, the dependent variables are total weekly work hours of male, female, and child household members. The regressions are otherwise identical to equation (1) except for the inclusion of controls for family age and gender composition. The estimates indicate that changes in male employment account for the majority of the program effect on hours. Higher male hours account for 11.4 of the implied total program effect of 13.8 hours (column (2)). Meanwhile, the difference in female hours (column (3)) is small and insignificant. 
TABLE VII

HOUSEHOLD Distribution OF WEEKLY HOURS

\begin{tabular}{|c|c|c|c|c|c|}
\hline \multirow[t]{2}{*}{ Universe: } & \multicolumn{3}{|c|}{ All households } & $\begin{array}{c}\text { (4) } \\
\text { Households } \\
\text { with children } \\
5-16\end{array}$ & $\begin{array}{c}(5) \\
\text { Households } \\
\text { with children } \\
5-16 \text { and }<4 \\
\text { working-age } \\
\text { members }\end{array}$ \\
\hline & Total hours & Men & Women & Children & Children \\
\hline $\begin{array}{l}\text { Number adult } \\
\text { men }\end{array}$ & $\begin{array}{l}19.71 \\
{[5.27]^{* *}}\end{array}$ & $\begin{array}{l}27.89 \\
{[3.75]^{* *}}\end{array}$ & $\begin{array}{c}-4.32 \\
{[2.65]}\end{array}$ & $\begin{array}{l}-2.32 \\
{[1.31]+}\end{array}$ & $\begin{array}{c}-2.51 \\
{[2.46]}\end{array}$ \\
\hline $\begin{array}{l}\text { Number adult } \\
\text { women }\end{array}$ & $\begin{array}{l}14.25 \\
{[4.20]^{* *}}\end{array}$ & $\begin{array}{c}-4.37 \\
{[2.65]}\end{array}$ & $\begin{array}{l}21.56 \\
{[2.45]^{* *}}\end{array}$ & $\begin{array}{l}-2.00 \\
{[1.06]+}\end{array}$ & $\begin{array}{l}-3.52 \\
{[1.55]^{*}}\end{array}$ \\
\hline $\begin{array}{l}\text { Number children } \\
\quad 5-11\end{array}$ & $\begin{array}{c}-4.13 \\
{[2.83]}\end{array}$ & $\begin{array}{l}-3.36 \\
{[1.84]+}\end{array}$ & $\begin{array}{l}-0.21 \\
{[1.65]}\end{array}$ & $\begin{array}{c}0.42 \\
{[0.93]}\end{array}$ & $\begin{array}{c}0.17 \\
{[0.66]}\end{array}$ \\
\hline $\begin{array}{l}\text { Number children } \\
\quad 12-16\end{array}$ & $\begin{array}{c}-2.82 \\
{[4.32]}\end{array}$ & $\begin{array}{c}-4.26 \\
{[2.94]}\end{array}$ & $\begin{array}{r}0.20 \\
{[2.39]}\end{array}$ & $\begin{array}{l}3.04 \\
{[1.28]^{*}}\end{array}$ & $\begin{array}{c}3.21 \\
{[1.93]+}\end{array}$ \\
\hline Squatter & $\begin{array}{l}-8.77 \\
{[4.39]^{*}}\end{array}$ & $\begin{array}{l}-5.52 \\
{[3.14]+}\end{array}$ & $\begin{array}{c}-2.83 \\
{[2.76]}\end{array}$ & $\begin{array}{c}0.24 \\
{[1.40]}\end{array}$ & $\begin{array}{c}1.29 \\
{[1.26]}\end{array}$ \\
\hline Squatter* program & $\begin{array}{l}13.78 \\
{[6.34]^{*}}\end{array}$ & $\begin{array}{l}11.44 \\
{[4.62]^{*}}\end{array}$ & $\begin{array}{c}1.58 \\
{[4.54]}\end{array}$ & $\begin{array}{c}0.66 \\
{[2.21]}\end{array}$ & $\begin{array}{l}-4.08 \\
{[1.87]^{*}}\end{array}$ \\
\hline $\mathrm{N}$ & 2,465 & 2,465 & 2,465 & 1,750 & 490 \\
\hline
\end{tabular}

Note: OLS regressions, specification detailed in notes to Table 4. Column (1) is same as column (1) of Table 4 except for inclusion of following controls: number adult men, number adult women, number children 5-11 and number children 12-16. In column (2), dependent variable is total hours of male working-age household members only; in column (3), dependent variable is total hours of female working-age household members only; in columns (4) and (5), dependent variable is total hours of children ages 5-16 only. Regressions 4-5 restricted to households with any children ages $5-16$, and regression 5 further restricted to households with fewer than 4 members aged 5-69. + implies statistical significance at $10 \%$ level, ${ }^{*}$ at $5 \%$ level, and ${ }^{* *}$ at $1 \%$ level.

The estimates reported in columns (4) and (5) examine the program effect on work hours of household members aged 5-16. As motivated by the model described in Section III, an increase in formal property rights is anticipated to lead to a decrease in child work hours if children have a comparative advantage in market work relative to home security. In the sample, $8.9 \%$ of all households report regular labor force participation (excluding unpaid domestic work) by children between ages five and 16, consistent with International Labor Office estimates (U.S. Department of Labor 1998). When the analysis is run on all households with children, the mean program effect on the probability of child labor is small and insignificant (column (4)). However, when the sample is restricted to households with fewer than four potential workers (members aged 5-69), the implied effect of titling is a 
reduction of 4 hours per week of child labor and is statistically significant at the $10 \%$ level. ${ }^{33}$ The importance of household size is consistent with the theoretical predictions and with Table IV results: if larger families are unconstrained by the need to keep family members at home, they have no incentive to send children to work in place of adults. While the estimated impact of titling on child work hours is consistent with the Section III prediction, the mechanism by which property titles reduce child labor is ambiguous. If child leisure is a normal good, the same prediction would follow from the income effect of added adult work hours. ${ }^{34}$

\section{V.F. Do Differences in Labor Supply Reflect Anticipatory Responses to the Program?}

Given that the program was targeted to every neighborhood in the analysis sample, an important interpretation issue is that control group members may adjust their behavior in anticipation of treatment. If trust in government is sufficiently high, the estimated treatment effects are a comparison of permanent title versus a temporary insecure state that is expected to lead to permanent security. While optimism about the future among those without title would generally bias the estimated program effect downward, it is also possible that future program participants spend a disproportionate amount of time safeguarding property in anticipation of the program due to extra security needs during this key period. In this case the measured effect is a short-run phenomenon that will subside once program activity has ended.

Discussions with COFOPRI administrators reveal that there was much uncertainty as to the timing and choice of specific program locations, making it unlikely that most households would feel confident in advance that the program would eventually enter their vicinity. ${ }^{35}$ Furthermore, given the political uncertainty during this era and the poor track record of government reforms in Peru, households are likely to have waited for proof of reform before adjusting their behavior. Indeed, three pieces of evidence suggest that the estimates are not driven by uncharacteristically

33. An analogous probit estimate indicates a 3.4-percentage point reduction in the probability of child labor among this subgroup.

34. This is also consistent with the finding that child labor in Peru responds to changes in the adult wage (Ray $2000 \mathrm{a}, 2000 \mathrm{~b}$ ).

35 . Indeed, the program was stopped on more than one occasion due to political turmoil, and there was speculation about whether it would continue after the 2000 elections (Gandolfo 2000). 
low work hours of squatters awaiting the program. First, the panel estimates give no indication that households that did not receive titles decreased labor hours between 1997 and 2000. Second, a program effect arising from uncharacteristic behavior of squatters in nonprogram areas is inconsistent with the Table $V$ finding that the IV estimate of program effect rises with time since titling began. In particular, if the findings are driven by reductions in squatters' work hours prior to being reached, excluding a subset of program neighborhoods should not increase the estimate. A third piece of evidence comes from examining the relationship between future program timing and preprogram labor supply. Since the program is officially announced some time before it begins and also indirectly announced by virtue of moving contiguously across neighborhoods (Figure I), households in neighborhoods soon to be titled should have higher expectations of being titled than households in neighborhoods that will be reached late. As a result, the extent to which households reduce labor force activity in anticipation of receiving a title should increase as the program approaches.

To examine this prediction, I restrict the sample to households titled after the 2000 baseline survey and construct a fourdigit index of nine-month periods of future program intervention between 2000 and 2003. I then estimate equation (1), replacing the measure of past timing with the index of future timing, in both the main effect and the interaction term between squatter and program timing. Results from these estimates are presented in Table VIII. The first two regressions examine the relationship between future program timing and subjective tenure security, with and without neighborhood fixed effects. As predicted, household insecurity rises with time to program entry (columns (1) and (2)), suggesting that households that are soon to be titled are more certain they will be reached. The fact that these households are not more likely to feel very secure (columns (3) and (4)) suggests that confidence that the program will begin does not fully eliminate households' uncertainty that they will be titled, which helps explain why anticipation of treatment does not entirely eliminate program effects.

In columns (5) and (6), the dependent variables are the same measures of labor supply studied in Table IV. If anticipatory effects are important, labor supply in 2000 should increase with future time to program among households in neighborhoods titled between 2000 and 2003. Meanwhile, the estimates give no indication that program order is related to household labor supply among 


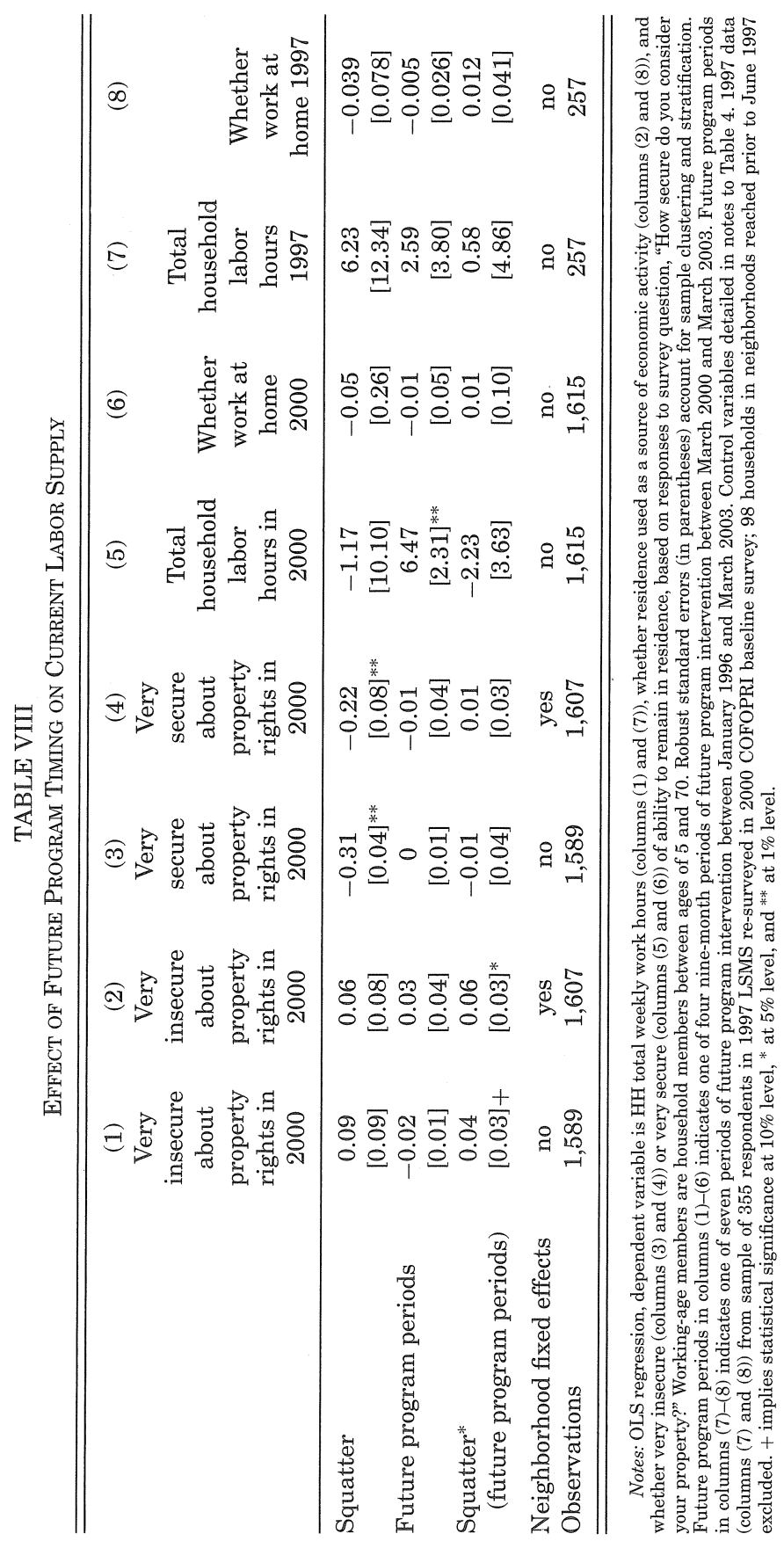


future beneficiaries. The last two estimates utilize households in the 1997-2000 panel to run an analogous control experiment, verifying that future program timing has no impact on 1997 labor hours. In this regression, program timing is a seven-digit variable, indicating seven waves of program expansion between 1997 and 2003. Once again, there is no evidence that anticipation of receiving a title influences preprogram labor supply.

\section{V.G. Other Channels of Program Impact}

It is possible that observed program effects operate through channels other than reduced need to protect property, such as increased credit availability. In general, increased credit access will bias program effect estimates downward by lowering the marginal utility of wage income. The potential endogeneity of credit access generates one notable complication in interpreting the home business outcome. Namely, titled households may be better able to cover the fixed cost of moving a business outside the home. However, this is inconsistent with the small number of loans used for business purposes, as well as evidence from four separate studies of credit effects of COFOPRI, in which titles were found to have no effect on business credit (Calderon Cockburn 1998; Torero 1999; Kagawa 2001; Field and Torero 2005). In light of earlier findings of reduced fertility among recently titled households, a related concern is that the program effect reflects differences in child care demands across comparison groups (Field 2004a; Galiani and Schargrodsky 2006). However, the fact that male hours account for the bulk of the labor supply response suggests that differences in fertility are not driving the results.

A more compelling story is the possibility that changes in incentives to invest in residential infrastructure on account of stronger property rights to land increased the marginal utility of labor income. Previous results indicate that home construction increased substantially in response to receiving a title, as is illustrated in Figure III (Field 2004b). Furthermore, the data indicate that borrowing constraints dampened the overall investment effect, further increasing incentives to work. Unfortunately, this pathway is difficult to rule out, given that both possible behavioral channels are direct responses to improvements in tenure security with similar patterns of predicted impact. For instance, investment responses are likely to be larger for households with weaker informal claims. One piece of evidence in support of the original 
URBAN PROPERTY RIGHTS AND LABOR SUPPLY IN PERU 1597

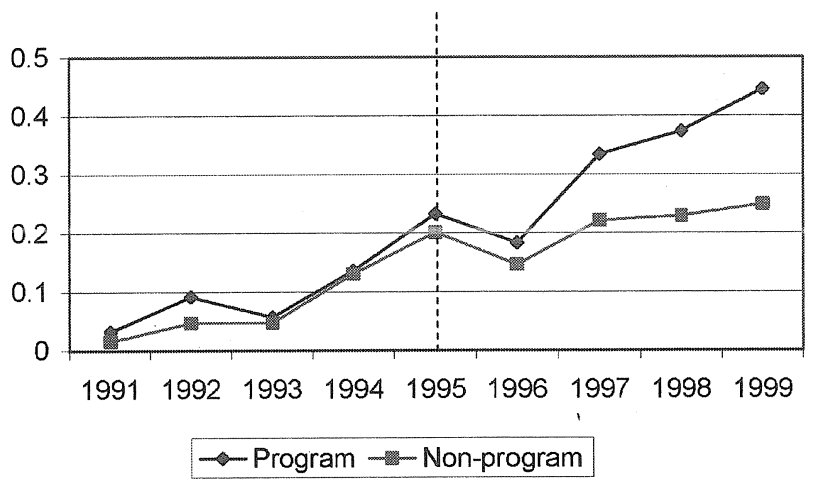

FIGURE III

Annual Number of Housing Renovations

Notes: Graph shows time trend in number of housing renovations per year between 1996 and 1999 among households living in neighborhoods that participated in the titling program and households in non-program neighborhoods. Retrospective data on housing renovations collected in the Baseline Survey (Instituto Cuánto 2000). Y-axis is yearly number of renovations made to the residence. The survey asked all households whether any of the following nine types of housing improvements ever took place and the year in which they occurred, in addition to asking whether and when any "other" improvements were made: new walls, new roof floor, electricity, plumbing, paint, new story, added bedroom, added story, added other room. The dotted line coincides with the onset of the titling program. The graph indicates a clear divergence in the rate of investment coinciding with the year in which the titling program began (1996). Details of this analysis can be found in Field (2004a).

interpretation is the strong relationship between household size and program response. Since household size, conditional on property size, is likely to be positively related to credit constraints, changes in labor supply driven by increases in investment incentives are predictably greater for larger households, whereas the estimate in column (3) of Table IV reveals the opposite pattern. Nevertheless, it is important to keep in mind that some of the observed program effect on labor supply may operate through changes in the marginal utility of labor income.

\section{CONCLUSIONS}

This paper provides new evidence on the economic returns to formalizing property rights in urban squatter communities in developing countries. By studying the relationship between acquisition of a property title and household labor supply, I provide empirical support for anecdotal evidence that untitled squatters commonly attain informal rights by taking time off of work to participate in private and community property protection. My 
results indicate that the cost of maintaining informal rights via reduced labor force hours and distortions in labor allocation is substantial. Unlike employment responses to most welfare programs, which tend to involve an income effect that potentially removes people from the labor force, government property titling programs appear to have the opposite effect on employment.

These findings imply a high cost-benefit ratio for government land titling programs. According to program data from Peru, a total of 1.2 million titles were eventually granted through the government program, such that the predictions from this analysis apply to roughly half a million households, or $10 \%$ of the national population. ${ }^{36}$ In contrast, the cost of the program amounted to an estimated $\$ 66$ per title, around $20 \%$ of which was recovered from user fees (World Bank 1998). The additional cost of maintaining a national property registry in terms of labor hours appears to be marginal-employment figures from public registry offices have actually fallen since the consolidation of the local registries. ${ }^{37}$ Thus, it is likely that the long-term benefit flows in wages far exceed the net cost of government titling.

The employment results can be added to a growing body of evidence on the value of urban land titling. Although existing studies indicate little effect of land titling on access to credit, there appear to be other important benefits of strengthening property rights in urban slums, including reduced fertility and increased investment in residential infrastructure (Field 2004a, 2004b, 2005; Field and Torero 2005; Galiani and Schargrodsky 2006). Understanding the multiple channels through which land titles influence economic outcomes is particularly important given that governments across the world are considering titling programs to address urban informality. ${ }^{38}$ In addition, the results have potential implications for understanding labor market frictions in developing countries (Cole 1996; Easterly 2001; Wasmer and Zenou 2002). In settings characterized by high levels of residential informality, informal property protection may constitute an important obstacle to labor market adjustment and economic growth.

36 . In the analysis sample, only $40 \%$ of newly registered titles were given to households that were previously untitled.

37. There is no indication that enforcement costs have risen, as evidenced by police expenditures.

38. The World Bank alone has sponsored several projects promoting formal property rights in urban slums (World Bank 2001). 
URBAN PROPERTY RIGHTS AND LABOR SUPPLY IN PERU 1599

APPENDIx I: Distribution of Households in SAMPLE

\begin{tabular}{lccr}
\hline \hline City & No program & Program & Total \\
\hline Lima & 200 & 510 & 710 \\
Arequipa & 0 & 160 & 160 \\
Trujillo & 110 & 50 & 160 \\
Chiclayo & 130 & 50 & 180 \\
Piura & 150 & 50 & 200 \\
Chimbote & 460 & 140 & 600 \\
Iquitos & 120 & 20 & 140 \\
Huancayo & 600 & 0 & 600 \\
Total & 1,770 & 980 & 2,750 \\
\hline \hline
\end{tabular}

Note: Cities listed in order of timing of program entry. Program and No program refer to whether the titling program entered neighborhood by March 2000. Program entry dates from the COFOPRI office.

ApPendix II: Summary Statistics by Timing of Program

\begin{tabular}{|c|c|c|c|c|c|c|c|}
\hline & & $(2)$ & (3) & (4) & (5) & (6) & (7) \\
\hline & \multicolumn{3}{|c|}{$\begin{array}{l}\text { Pre-program Squatter HHs } \\
\qquad(N=656)\end{array}$} & \multicolumn{3}{|c|}{$\begin{array}{l}\text { Pre-program titled } \mathrm{HHs} \\
\qquad(N=2081)\end{array}$} & \multirow[b]{2}{*}{$\left|t_{\Delta}^{2}\right|$} \\
\hline & $\begin{array}{c}\text { Program } \\
\text { 1998-1999 }\end{array}$ & $\begin{array}{c}\text { Program } \\
1996-1997 \\
\end{array}$ & $\left|t_{\Delta}\right|$ & $\begin{array}{c}\text { Program } \\
1998-1999 \\
\end{array}$ & $\begin{array}{c}\text { Program } \\
1996-1997 \\
\end{array}$ & $\left|t_{\Delta}\right|$ & \\
\hline Female head of $\mathrm{HH}$ & 0.22 & 0.24 & 0.20 & 0.20 & 0.19 & -0.10 & -0.22 \\
\hline Age head & 47.13 & 47.69 & 0.15 & 48.33 & 50.17 & 1.10 & 0.35 \\
\hline $\begin{array}{l}\text { Mean age of } \mathrm{HH} \\
\text { member }\end{array}$ & 26.45 & 26.70 & 0.11 & 28.51 & 29.10 & 0.65 & 0.16 \\
\hline HH size (\# members) & 5.01 & 5.46 & 0.92 & 5.46 & 5.42 & -0.13 & -0.69 \\
\hline \# members ages 5-59 & 3.93 & 4.41 & 1.12 & 4.31 & 4.40 & 0.28 & -0.57 \\
\hline Lot size (m2) & 146.54 & 178.48 & 1.01 & 195.78 & 172.49 & -1.09 & -1.44 \\
\hline $\begin{array}{l}\text { Education head }> \\
\text { primary school }\end{array}$ & 0.37 & 0.30 & -0.95 & 0.39 & 0.34 & -0.87 & 0.47 \\
\hline $\begin{array}{l}\text { Residence acquired } \\
\text { by invasion }\end{array}$ & 0.22 & 0.14 & -1.08 & 0.24 & 0.13 & -2.54 & -0.42 \\
\hline Tenure & 15.41 & 15.77 & 0.14 & 16.53 & 19.32 & 1.93 & 0.94 \\
\hline $\begin{array}{l}\text { HH adult literacy } \\
\text { rate }\end{array}$ & 0.91 & 0.99 & 1.59 & 0.93 & 0.99 & 2.06 & -0.34 \\
\hline $\begin{array}{l}\text { Municipal service } \\
\quad \text { (water) }\end{array}$ & 0.80 & 0.84 & 0.42 & 0.90 & 0.93 & 0.62 & -0.22 \\
\hline Whether $\mathrm{HH}$ saves & 0.13 & 0.04 & -1.78 & 0.09 & 0.06 & -1.31 & 1.02 \\
\hline $\begin{array}{l}\text { HH Monthly expend. } \\
\quad(\mathrm{S} /)\end{array}$ & 425.12 & 544.12 & 1.82 & 560.67 & 638.02 & 0.94 & -0.79 \\
\hline Weekly labor hours & 79.16 & 124.89 & 3.07 & 106.94 & 108.49 & 0.13 & -2.15 \\
\hline $\begin{array}{l}\text { Labor force } \\
\text { participation rate }\end{array}$ & 0.52 & 0.56 & 0.73 & 0.53 & 0.54 & 0.40 & -0.44 \\
\hline $\begin{array}{l}\text { Whether work in } \\
\text { home }\end{array}$ & 0.29 & 0.16 & -1.33 & 0.32 & 0.22 & -1.44 & 0.18 \\
\hline $\begin{array}{l}\text { Whether any } \mathrm{HH} \\
\text { member commutes } \\
\text { more than } 2 \text { hours }\end{array}$ & 0.09 & 0.01 & -1.46 & 0.05 & 0.03 & -0.89 & 0.97 \\
\hline
\end{tabular}




\begin{tabular}{|c|c|c|c|c|c|c|c|}
\hline \multicolumn{8}{|c|}{$\begin{array}{c}\text { APPENDIX II } \\
\text { (CONTINUED) }\end{array}$} \\
\hline & & (2) & (3) & (4) & (5) & (6) & (7) \\
\hline & \multicolumn{3}{|c|}{$\begin{array}{l}\text { Pre-program Squatter HHs } \\
\qquad(N=656)\end{array}$} & \multicolumn{3}{|c|}{$\begin{array}{l}\text { Pre-program titled } \mathrm{HHs} \\
\qquad(N=2081)\end{array}$} & \\
\hline & $\begin{array}{c}\text { Program } \\
1998-1999 \\
\end{array}$ & $\begin{array}{c}\text { Program } \\
1996-1997 \\
\end{array}$ & $\left|t_{\Delta}\right|$ & $\begin{array}{c}\text { Program } \\
1998-1999 \\
\end{array}$ & $\begin{array}{c}\text { Program } \\
1996-1997 \\
\end{array}$ & $\left|t_{\Delta}\right|$ & $\left|t_{\Delta}^{2}\right|$ \\
\hline $\begin{array}{l}\text { Participation in } \\
\text { neighborhood } \\
\text { work group } \\
\text { before titling }\end{array}$ & 0.45 & 0.70 & 1.59 & 0.53 & 0.61 & 1.33 & -1.11 \\
\hline $\begin{array}{l}\text { Participation in } \\
\text { government } \\
\text { welfare program }\end{array}$ & 0.34 & 0.40 & 0.81 & 0.33 & 0.35 & 0.33 & -0.30 \\
\hline
\end{tabular}

Note: Raw sample means from COFOPRI Baseline Survey (Instituto Cuanto, 2000). Columns (3) and (6) report the $t$-statistics of the difference between columns (1) and (2), and (4) and (5). Column (7) reports the $t$-statistic of the difference in difference (3-6). Program dates refer to whether the titling program entered the neighborhood in 1998 and 1999 (periods 3 and 4), or in 1996 and 1997 (periods 1 and 2). Tenure is equal to 2001 minus the reported number of the years then that dwelling has been inhabited by a member of the respondent's household. Exchange rate in March 2000 was 3.44 soles to the dollar.

HaRVARd University and National BuREaU of Economic Research

\section{REFERENCES}

Acemoglu, Daron, Simon Johnson, and James Robinson, "Colonial Origins of Comparative Development: An Empirical Investigation," American Economic Review, 91 (2001), 1369-1401.

- "Reversal of Fortune: Geography and Institutions in the Making of the Modern World Income Distribution," Quarterly Journal of Economics, 117 (4) (2002), 1231-1294.

Alchian, A., and H. Demsetz, "The Property Rights Paradigm," Journal of Economic History, 33 (1973), 16-27.

Alston, Lee J., G. D. Libecap, and B. Mueller, Titles and Land Use: The Development of Property Rights on the Brazilian Amazon (Ann Arbor, MI: University of Michigan Press, 1999).

Apoyo Consultoría, "Encuesta de Línea de Base: Reporte Final," November 2000.

Baharoglu, Deniz, "World Bank Experience in Land Management and the Debate on Tenure Security," World Bank Housing Research Background-Land Management Paper, 2002.

Banerjee, Abhijit, Paul Gertler, and Maitresh Ghatak, "Empowerment and Efficiency: Tenancy Reform in West Bengal," Journal of Political Economy, 110 (2) (2002), 239-280.

Basu, Kaushik, and P. H. Van, "The Economics of Child Labor," American Economic Review, 88 (3) (1998), 412-427.

Besley, Tim, "Property Rights and Investment Incentives: Theory and Evidence from Ghana," Journal of Political Economy, 103 (5) (1995), 903-937.

Binswanger, Hans, Klaus Deninger, and Gershon Feder, "Power, Distortions, Revolt, and Reform in Agricultural Land Relations," in Handbook of Development Economics, Volume IIIB, Jere Behrman and T. N. Srinivasan, eds. (Amsterdam: Elsevier, 1995).

Calderon Cockburn, J., "Regularisation of Urban Land in Peru," in Land Lines (Cambridge, MA: Lincoln Institute of Land Policy, May 1998).

Carter, Michael, and Pedro Olinto, "Getting Institutions Right for Whom? The Wealth Differentiated Impact of Property Rights Reform on Investment and Income in Rural Paraguay." University of Wisconsin, Working Paper, 1996. 
Carter, Michael, and Keith Wiebe, "Tenure Security for Whom? An Econometric Analysis of the Differential Impact of Land Titling Programs in Kenya" in Land Tenure Reform in Sub-Saharan Africa, S. Migot-Adholla and J. Bruce, eds. (Dubuque, IA: Kendall/Hunt Press, 1994).

Clay, Karen B., "Squatters, Production, and Violence." (http://ssrn.com/ abstract $=886553,2006)$.

COFOPRI, mimeo, COFOPRI Office, Lima, Peru, June 2000

Cole, William E., "Labor Migration and Urban Employment in Developing Countries: The Impact of Population Growth and Property Institutions," in The Institutional Economics of the International Economy, John Adams and Anthony Scaperlanda, eds. (Boston: Kluwer Academic, 1996).

Conger, Lucy, "Entitled to Prosperity," Urban Age Magazine, The World Bank Group, Fall 1999 Issue.

Demsetz, H., "Toward a Theory of Property Rights," American Economic Review, 57 (1967), 347-539.

De Soto, Hernando, The Other Path (New York: Harper and Row Publishers, 1990).

Easterly, William, "The Lost Decades: The Developing Countries Stagnation in Spite of Policy Reform," Journal of Economic Growth, 9 (2001), 135-157.

Feder, Gershon, Tongroj Onchan, Yongyuth Chalamwong, and Chira Hongladarom, Land Policies and Farm Productivity in Thailand (Baltimore: Johns Hopkins University Press, for the World Bank, 1988).

Field, Erica, "Entitled to Work: Urban Property Rights and Labor Supply in Peru," Research Program in Development Studies Working Paper \#223, Princeton University, 2003.

_-, "Fertility Responses to Urban Land Titling Programs: The Roles of Ownership Security and the Distribution of Household Assets," mimeo, Harvard University, June 2004a.

_- "Property Rights, Community Public Goods and Household Time Allocation in Urban Squatter Communities," William and Mary Law Review, 45 (3) (2004b), 837-887.

, "Property Rights and Investment in Urban Slums," Journal of the European Economic Association Papers and Proceedings, 3 (2-3) (2005), 279-290.

Field, Erica, and Maximo Torero, "Do Property Titles Increase Credit Access among the Urban Poor? Evidence from Peru," mimeo, Harvard University, March 2006.

Galal, A., and O. Razzaz, "Reforming Land Markets," Policy Research Working Paper 2616, World Bank, 2001.

Galiani, Sebastian, and Ernesto Schargrodsky, "Property Rights for the Poor: Effects of Land Titling," mimeo, UTDT, 2006.

Gandolfo, Carlos, personal interview, COFOPRI Office, Lima, August 9, 2000.

IADB, "PETT Rural Titling Survey," Inter-American Development Bank, Washington, DC, 2004.

INEI, "IX Censo de Población y IV de Vivienda 1993," Instituto Nacional de Estadísticas y Informática, 1993.

Instituto Cuánto, "Living Standards Measurement Survey 1997," Lima, 1997.

_- "Encuesta de Linea de Base (Baseline Survey)," Instituto Cuánto, Lima, 2000.

Kagawa, Ayako, "Policy Effects and Tenure Security Perceptions of Peruvian Urban Land Tenure Regularisation Policy in the 1990s," Workshop Paper, ESF/N-AERUS International Workshop, Leuven and Brussels, Belgium, 2326 May 2001.

Kimuyu, Peter K., "Credit and Financial Markets," in Policy and Rural Development: Two Communities in East Africa, Thomas C. Pinckney, ed. (Williamstown, MA: Williams College Center for Development Economics, 1994).

Lanjouw, J. O., and Philip Levy, "Untitled: A Study of Formal and Informal Property Rights in Urban Ecuador," The Economic Journal, 112 (482) (2002), 9861019.

Living Standards Measurement Survey, World Bank, 1997.

Lopez, R., and C. Romano, "Rural Poverty in Honduras: Asset Distribution and Liquidity Constraints," University of Chicago, Working Paper, 1997. 
Miceli, Thomas J., C. F. Sirmans, and Joseph Kieyah, "The Demand for Land Title Registration: Theory with Evidence from Kenya," American Law and Economics Review, 3 (2) (2001), 275-287.

North, Douglas C., Structure and Change in Economic History (New York: W.W. Norton \& Co., 1981).

Olórtegui, Ingrid G. Informal Settlers in Lima, presented at the ESF/N-AERUS International Workshop, Leuven and Brussels, Belgium, 23-26 May 2001.

Place, F., and S. Migot-Adholla, "Land Registration and Smallholder Farms in Kenya," Land Economics, 74 (3) (1998), 360-373.

Ray, Ranjan, "Analysis of Child Labor in Peru and Pakistan," Journal of Population Economics, 13 (2000a), 3-19.

- "Child Labor, Child Schooling and Their Interaction with Adult Labor," The World Bank Economic Review, 14 (2) (2004b), 347-367.

Rowe, John Howland, "Review of Power and Property in Inca Peru," The Hispanic American Historical Review, 40 (1) (1960), 126-127.

Schady, Norbert, "Picking the Poor: Indicators for Geographic Targeting in Peru," World Bank Working Paper, Number 2477, 2002.

Schmidt, Gregory D., "Delegative Democracy in Peru? Fujimori's 1995 Landslide and the Prospects for 2000," Journal of Inter-American Studies and World Affairs, 42 (2004), 1-121.

Shleifer, Andrei, and Robert W. Vishny, "Corruption," The Quarterly Journal of Economics, 108 (3) (1993), 599-617.

Torero, Maximo, "Estudio de la Oferta,, Demanda y Fuentes de Credito Informal," Documento Suplementario del Estudio: Perfil de la Demanda y Oferta del Credito Formal y Informal, paper prepared for the COFOPRI office, Grupo de Analisis para el Desarollo, 1999.

U.S. Department of Labor, "By the Sweat and Toil of Children: Volume V: Efforts to Eliminate Child Labor" Bureau of International Labor Affairs, Washington, DC, 1998 (http://www.dol.gov/ilab/media/reports/iclp/sweat5/).

Wasmer, E., and Y. Zenou, "Does City Structure Affect Job Search and Welfare?" Journal of Urban Economics, 53 (3) (2002), 515-541.

World Bank, "The Legal and Institutional Framework," ANNEX A1, Urban Property Rights Project, World Bank Internal Paper, Washington, DC, 1997.

- "Project Appraisal Document," Report No.18245PE, Peru-Urban Property Rights Project, Washington, DC, 1998.

_- Project Report \#18359-IND, World Bank, Washington, DC, 2000. "Land, Security, Property Rights and the Urban Poor: Twenty Five Years of World Bank Experience," World Bank Briefing Note 8, 2001.

Yi Yang, Zoila Z., COFOPRI, An Experience of Land Tenure Regularization in Informal Settlements in Perú: Regularisation Process Case Study at the Saul Cantoral Settlement, paper prepared for the Advanced International Training Programme, Housing and Development, Lund Institute of Technology School of Architecture, 1999. 